https://doi.org/10.18485/iipe_cpti.2020.ch9

\title{
JAČANJE DESNICE KAO STRAŠILO: SLUČAJ SR NEMAČKE
}

\begin{abstract}
Dušan DOSTANIĆ1
Apstrakt: Poslednjih godina se sve više govori o rastu desnice, pri čemu se na taj rast gleda kao na potencijalnu opasnost, odnosno bezbednosni izazov. Autor u tekstu pokušava da na primeru SR Nemačke odgovori da li i koliko ta dominantna teza ima podlogu u stvarnosti. Budući da svaka evropska zemlja sa svojim istorijskim razvojem predstavlja slučaj za sebe, autor se $u$ radu bavi prvenstveno situacijom $u$ Nemačkoj, imajući $u$ vidu pre svega povesnu specifičnost nemačke desnice, kao i to da je reč o zemlji koja je dugo vremena bila bez značajne stranke na desnici. Rad je podeljen u četiri dela. Pošto se o rastu ili opadanju nekog fenomena može govoriti samo u okviru istorijskog konteksta, autor rad započinje kratkom polemikom o položaju i uticaju savremene evropske desnice, stavljajući u fokus pitanje opravdanosti percepcije „rasta“ desnice kao bezbednosne pretnje. Potom pažnju posvećuje istorijatu nemačke desnice i hronologiji njenog potiskivanja iz političkog života. U drugom delu rada analiziran je program i pozicija Alternative za Nemačku (AfD), kao najvažnije desne stranke u Nemačkoj, dok se u trećem delu govori o desnici izvan AfD. Četvrti deo posvećen je pitanju međunarodne saradnje desnih stranaka.

Ključne reči: desnica, konzervativizam, SR Nemačka, Alternativa za Nemačku, bezbednost.
\end{abstract}

Nakon referenduma o izlasku Velike Britanije iz Evropske unije i predsedničkih izbora u Sjedinjenim Američkim Državama, usledili su uspesi desnih, konzervativnih stranaka širom Evrope. U Austriji je Slobodarska partija formirala vladu, Marin Le Pen (Marine Le Pen) je ušla u drugi krug predsedničkih izbora u Francuskoj, da bi godinu dana kasnije u Italiji Liga, istina u koaliciji, došla na vlast. Ono što je jednima izgledalo kao „patriotsko

\footnotetext{
${ }^{1}$ Autor je istraživač-saradnik u Institutu za političke studije, Beograd, e-mail: dusan.dostanic@ips.ac.rs
} 
proleće“ ili kao „demokratska pobuna“, drugi su videli kao talas „desnog populizma“, pa čak i kao uspehe "krajnje desnice“. Pri tome nije reč o vrednosno neutralnoj konstataciji, jer kada se u medijima, ali i u akademskoj javnosti govori o "rastu desnice“ , po pravilu se na taj rast gleda sa izvesnom zabrinutošću. Pada u oči da kada je reč o uspesima levice takav ton izostaje, te se jačanje levice, čak i one radikalne, često dočekuje sa odobravanjem ili pak sa entuzijazmom, kao da se totalitarne pretenzije mogu očekivati jedino zdesna. Iako u konzervativnim, desnim idejama nema ničeg što bi ih same po sebi činilo opasnim i problematičnim, ${ }^{2}$ posle Drugog svetskog rata, a posebno nakon šezdesetih godina XX veka, formirao se asocijativni lanac prema kome je sve što je konzervativno i desno, ${ }^{3}$ isto što i reakcionarno, ekstremističko, nasilničko i fašističko, pri čemu se totalitarne tendencije kod levice potpuno ispuštaju iz vida. Kao primer ovakvog odnosa prema konzervativizmu i desnici može da posluži istorija ideologija poznatog profesora Klausa fon Bajmea (Klaus von Beyme), gde deo koji se bavi konzervativizmom nosi naslov Teorije konzervativizma i desnog ekstremizma, dok se u naslovu toma koji se bavi levicom ne pominje ekstremizam, nego

\footnotetext{
${ }^{2} \mathrm{Na}$ ovom mestu ne možemo ulaziti u načelno pitanje mogu li uopšte postojati "problematične ideje“ odnosno da li postoje ideje koje bi bile imune na lošu upotrebu, te da li ta loša upotreba može diskreditovati svaku ideju.

${ }^{3}$ Samo po sebi se nameće pitanje odnosa između konzervativizma i desnice, budući da su oba pojma bez preciznog određenja. Najveći broj autora, ali i samih konzervativaca drži da konzervativizam pripada desnici, prihvatajući formulu Erik fon Kinelt Ledina (Erik von Kuehnelt-Leddihn) "Right is right and left is wrong“. Ipak, postoje i oni konzervativci koji insistiraju na tome da ne pripadaju desnici, ali i oni koji su naglašavali da ne samo da su konzervativni, nego su i desničari (Moler, Vajsman). Moguće je ovom problemu prići sa druge strane i postaviti pitanje - da li je zamislivo postojanje desnice koja nije konzervativna? Tako je u francuskom kontekstu desnica širi pojam od konzervativizma i obuhvata tri struje: legitimističku, bonapartističku i orleanističku odnosno liberalnu desnicu. U heterogenu „novu desnicu“ s kraja XX veka O'Saliven (Noël O'Sullivan) ubraja ekonomske liberale (austrijska i čikaška škola, ordo liberali), konzervativce okupljene oko britanskih i američkih časopisa (Salisbury Review, National Review, New Republic, The Public Interest) te nešto što naziva „,radikalna nova desnica" sa Alenom de Benoom (Alain de Benoist) kao glavnim predstavnikom. (Noël O'Sullivan, „The New Right: The Quest for a Civil Philosophy in Europe and America“" in: Roger Eatwell, Noël O'Sullivan (ed.) The Nature of the Right: American and European Political Thought Since 1789, Printer Publishers, London, 1989, p. 170.) Na ovom mestu nije moguće detaljnije ulaziti u finese pojmovnog određenja. Umesto toga dovoljno je reći da ćemo u ovom radu konzervativizam posmatrati kao deo desnice i njenog najizrazitijeg predstavnika.
} 
se izričito nabrajaju socijalizam, komunizam i anarhizam. Time se već u naslovu sugeriše postojanje suštinske veze između konzervativizma i desnog ekstremizma, pa izgleda da je razlika među njima jedino u stepenu, dok se kod levice govori o tri zasebna idejna pravca. ${ }^{4}$ Drugim rečima: „Lak je prelazak od reakcionarne na neofašističku poziciju" - kako to otvoreno tvrde radikalno levi autori - pa je sledstveno i "kretanje udesno“ shvaćeno kao "stvarna pretnja demokratiji“ " ${ }^{5} \mathrm{~S}$ druge strane, čak i u slučajevima levičarskog nasilja mediji izbegavaju da govore da iza toga stoje levičari, nego upotrebljavaju izraze kao što su "autonomni“ ili „protivnici globalizacije“. ${ }^{6}$ Nasuprot tome, svaki izborni uspeh neke desne stranke bilo gde u Evropi dočekuje se sa nervozom, kao da je reč o uvertiri za novi „Marš na Rim“ koji samo što nije otpočeo. ${ }^{7}$ Uopšte, bavljenje desnicom ili „konzervativizmom retko je objektivne, već je po pravilu polemičke prirode". ${ }^{8}$

Ipak, pored ovog negativnog odnosa prema desnici poslednjih godina posebno je uočljiva opsesija "rastom“ desnice. Ilustrativan primer pruža brošura Desni ekstremizam u Srbiji koja počinje rečima: „Desni ekstremizam godinama je globalni rastući fenomen, koji još nema snažnog intelektualnog i političkog odgovora. Promene na političkoj sceni, u nekim od vodećih demokratskih zemalja i dolazak konzervativnih populista na vlast, ohrabrilo

${ }^{4}$ Klaus von Beyme, Konservatismus: Theorien des Konservatismus und Rechtsextremismus im Zeitalter der Ideologien 1789-1945, Springer Fachmedien Wiesbaden 2013. O izjednačavanju desnice i desnog ekstremizma u svakodnevnom govoru vidi: Rainer Zitelmann, „Position und Begriff - Über eine neue demokratische Rechte" in: Heimo Schwilk, Ulrich Schacht (Hrsg.), Die selbstbewusste Nation: "Anschwellender Bocksgesang" und weitere Beiträge zu einer deutschen Debatte, Ullstein, Berlin, 1994, S.163-166. Takođe vidi: Alen De Benoa, Komunizam i nacizam: 25 ogleda o totalitarizmu u XX veku (19171989), Centar za izučavanje tradicije „Ukronija“, Beograd, 2007.

${ }^{5}$ Jörg Berlin, Dierk Joachim, Bernhard Keller, Volker Ulrich, „Neofašizam u Saveznoj Republici Nemačkoj“ u: Marksizam u svetu, br. 4-5, Beograd, 1983, str. 268, 271.

${ }^{6}$ Hans-Olaf Henkel, „Der deutsche Migrations-Skandal“ in: Cicero, https://www. cicero.de/wirtschaft/der-deutsche-migrations-skandal/38250 20/4/2020.

${ }^{7}$ Nakon izbornog uspeha Alternative za Nemačku (AfD) i ulaska u Bundestag deo svetske štampe doneo je, između ostalih, vesti o „Hitleru u parlamentu“, stranci koja u svojim redovima ima rasiste i istorijske revizioniste, te o "nacističkoj aveti“. Vidi: „Hitler im Parlament", Frankfurter Allgemeine Zeitung, https://www.faz.net/aktuell /politik/bundestagswahl/internationale-reaktionen-auf-die-bundestagswahl15216062.html?printPagedArticle=true\#pageIndex_831/5/2020.

${ }^{8}$ Karlheinz Weißmann, Kurze Geschichte der konservativen Intelligenz nach 1945, Institut für Staatspolitik, Schnellroda, 2011, S. 8. 
je desničare u njihovom fanatizmu. ${ }^{\prime 9}$ Iako je reč o nemarno sastavljenoj, konfuznoj, površnoj i tendencioznoj brošuri, u dve rečenice sažete su sve ključne tačke dominantne priče o desnici. Naglašava se da je reč o „globalnom rastućem fenomenu“, zatim se dodaje da na njega nema "snažnog intelektualnog i političkog odgovora", čime se sugeriše da je reč ne samo o "fenomenu" nego o problemu koji zahteva "snažan odgovor". Pored toga, sugeriše se postojanje veze između pobede "konzervativnih populista" i "desničarskih fanatika“. Rečju, desnica ne samo da je potencijalno opasna, nego se tvrdi i da je u stalnom porastu, što dodatno povećava bojazan od lošeg ishoda i nalaže mobilizaciju svih ostalih kako bi se taj rast zaustavio, te predupredile njegove posledice. Ovakva mišljenja vrlo dobro ilustruje članak Ralfa Zočeka (Ralf Sotscheck) u kome sve različite desne političare od Trampa, preko Salvinija, Kačinskog, Gaulanda do Orbana, optužuje za fašizam i sa njima odbija svaki eventualni razgovor. Kao odgovor na ovu navodnu fašističku opasnost Zoček predlaže, ni manje ni više, nego direktnu akciju po uzoru na Grupu 43, koja se posle rata u Britaniji uličnim nasiljem suprotstavljala nacionalističkim i fašističkim strujama. ${ }^{10}$ "Rast " desnice time prestaje da bude konstatacija stanja i postaje nešto poput zvona za uzbunu. Pri tome se vrlo retko čuje o "padu“ desnice. Još čudnije je da je u današnje vreme tek mali broj ljudi spreman da se nedvosmisleno identifikuje sa desnicom. Ovu pojavu konstatovao je Armin Moler sedamdesetih godina. Još tada su svi koji nisu levičari želeli da budu "u centru“ ili barem malo desnije od centra, ali nikada na desnici. ${ }^{11}$ Čak i oni koji ne mogu da izbegnu priznanje da pripadaju desnici nastoje da to ublaže, pa o sebi govore kao o "modernim", "umerenim“, "saosećajnim“ konzervativcima, ili kao o pripadnicima "desnog centra". Izgleda da desnica prkosi prirodnim zakonima time što, iako malo ko želi da se nazove desničarem, može stalno da bude $u$ porastu, a da pri tome uistinu nikada ne naraste. ${ }^{12}$ Ona, s jedne

\footnotetext{
${ }^{9}$ Izabela Kisić (ur.) Desni ekstremizam u Srbiji, Helsinški odbor za ljudska prava u Srbiji, Beograd, 2020, str. 3. Takođe vidi: Jovo Bakić, Evropska krajnja desnica, (1945-2018), Clio, Beograd, 2019. Tu se desnica takođe shvata kao "opasnost" koja jača i na više mesta se podvlači politička bliskost između konzervativaca i krajnjih desničara.

${ }^{10}$ Ralf Sotscheck, „Nicht naiv Testballons jagen“, taz, https:/ / taz.de/Debatte-MitRechten-reden/!5555657/ 31/5/2020.

${ }^{11}$ Armin Mohler, Von rechts gesehen, Seewald Verlag, Stuttgart, 1974, S. 42.

${ }^{12} \mathrm{Na}$ ovom mestu nemamo prostora da ulazimo bliže u razmatranje ovog pitanja, ali kada je Nemačka u pitanju, izgleda da se u svakoj deceniji od početka šezdesetih godina govorilo o novom „, usponu desnice“ ili čak o novoj „,neonacističkoj opasnosti“.
} 
strane, stalno jača, dok je s druge strane uvek u podzemlju i na margini, daleko od učešća u vlasti, redakcija velikih medijskih kuća, univerziteta ili uticajnih fondacija. Iako na margini, ona je uvek prisutna kao strašilo i sredstvo za okupljanje njenih protivnika. Samo po sebi postavlja se pitanje kako je tako nešto uopšte moguće? Svakako, kada u Nemačkoj jedna stranka desnice, četiri godine posle svog osnivanja, osvoji 12,6\% glasova na saveznim izborima, kao i mesta u svim pokrajinskim skupštinama, na prvi pogled se nameće zaključak da je nesumnjivo reč o jačanju desnice. Ne ukazuje li ulazak kandidata desnih stranaka u drugi krug predsedničkih izbora $\mathrm{u}$ Austriji 2016, i u Francuskoj 2017, stvarno na rast desnice u Evropi? Na prvi pogled, to može tako izgledati, ali se nužno postavlja pitanje: rast u odnosu na šta? Tek kada se nešto zna o istorijskom kontekstu moguće je izvesti zaključke o dometima tog rasta, kao i o tome šta uopšte u određenom kontekstu važi za "levo“ ili za "desno“.

Posebno pitanje je da li je taj rast nešto što se može posmatrati kao opasnost ili ne, odnosno zašto je situacija u kojoj u drugi krug predsedničkih izbora idu kandidat levice i kandidat desnice (kao u Austriji), lošija od one u kojoj se nadmeću dva kandidata između kojih jedva da se može praviti razlika? Čak i kada bi se složili da desnica na nekim izborima prolazi bolje nego ranije, može li se na to reagovati staloženije i bez paničnih poziva na mobilizaciju, pa čak i nasilje? I na ovo pitanje moguće je odgovoriti samo ako se pre toga nešto kaže o istorijskom kontekstu, odnosno o snažnom pomeranju čitavog političkog i medijskog spektra ka levici do koga je u zapadnoj Evropi došlo tokom šezdesetih godina $X X$ veka. Naravno, $u$ različitim evropskim državama taj proces se odvijao različitom brzinom i na različite načine, te na ovom mestu nije moguće govoriti o čitavoj Evropi. Umesto toga, govorićemo o nemačkom slučaju koji zbog istorijskih razloga važi za najmarkantniji i koji je privlačio najviše pažnje budući da je Nemačka dugo vremena važila za zemlju u kojoj nije postojala istinska desna, konzervativna stranka.

\section{Nemačka desnica posle 1945.}

Istoriju nemačke desnice treba početi od 1945. godine, budući da je ona bila od ključnog značaja za nemački konzervativizam. Komunisti, socijalisti, liberali i katolici mogli su posmatrati poraz Nemačke iz 1945. kao katastrofu, ali je on to mnogo više bio za nemačke konzervativce, budući da je ratni 
poraz bio i poraz desnice $\mathrm{u}$ celini. ${ }^{13}$ Ipak, konzervativizam nikada nije predstavljao homogenu celinu, pa ni za vreme Trećeg rajha. Jedan deo konzervativaca je iz rata izašao sa mrljom kraće ili duže saradnje sa Hitlerovim pokretom, dok je drugi deo kraj rata dočekao sa zamašnim moralnim kapitalom koji je poticao iz učešća u otporu Hitlerovom režimu. Tokom Trećeg rajha mnogi konzervativci su ubijeni (Edgar Julijus Jung, Kurt fon Šlajher), drugi su bili zatočeni u logorima (Ernst Nikiš, Martin Nimeler), dok su treći otišli u emigraciju (Ernst Kantorovic). Čak i oni koji su ostali u zemlji kao Karl Šmit (Carl Schmitt) ili Ernst Jinger (Ernst Jünger) živeli su u tzv. "unutrašnjoj emigraciji“. ${ }^{14}$ Štaviše, najozbiljniji otpor Hitlerovom režimu došao je sa pozicija političke desnice. Glavni organizator atentata na Hitlera 1944. godine bio je pukovnik Fon Štaufenberg (Claus Schenk Graf von Stauffenberg) koji je još kao mladić pripadao krugu oko pesnika Štefana Geroga (Stefan Gerorge). ${ }^{15}$ Neuspeli atentat bio je i poslednji čin prusko-nemačkog konzervativizma. Tako se nemačka desnica 1945. godine našla u neobičnoj poziciji. S jedne strane, kao ideološki i aktivni protivnik Hitlerovog režima konzervativna desnica (ili barem jedan njen deo) raspolagala je moralnim autoritetom, dok su, s druge strane, poraz i bezuslovna kapitulacija iz 1945. bili ne samo poraz režima nego i nacionalne države, te stoga i poraz nacionalne desnice, čak i onda kada je ona bila antihitlerovski orijentisana. Prema rečima liberala Teodora Hojsa (Theodor Heuss), Nemačka je paradoksalno 1945. bila "pobeđena i oslobođena“ istovremeno. ${ }^{16}$ Zapravo, država na nemačkom tlu faktički nije ni postojala,

${ }^{13}$ Weißmann, Kurze Geschichte der konservativen Intiligenz nach 1945, S. 17.

${ }^{14}$ Ovome se ne treba čuditi ako se ima u vidu da je nacional-socijalistički režim uprkos svojoj retorici u osnovi bio modernistički, te prema tome antikonzervativan. $\mathrm{O}$ modernosti nacional-socijalizma vidi: Rainer Zitelmann, „Die totalitäre Seite der Moderne“, in: Michael Prinz und Rainer Zitelmann (Hrsg.), Nationalsozialismus und Modernisierung, Wissenschaftliche Buchgesellschaft, Darmstadt, 1991, S. 1-20.

${ }^{15}$ Hans-Christof Kraus, „Das Geheime Deutschland: Zur Geschichte und Bedeutung einer Idee“" Historische Zeitschrift, Band 291, Oldenbourg, 2010, S. 385-417. Pored Štaumfenberga vođe zavere su bili general Ludvig Bek (Ludwig Beck) i političar monarhističke orijentacije Karl Fridrih Gerdeler (Carl Groedeler). O Gerdeleru vidi: Gerhard Ritter, Carl Groedeler und die deutsche Widerstandsbewegnung, Deutsche Verlags-Anstalt, Stuttggart, 1956.

${ }^{16}$ Stefan Winckler, „Konservative Intelligenz in vereinigten Deutschland“ in: Die kupierte Alternative, Konservatismus in Deutschland nach 1945, Frank-Lothar Kroll (Hrsg), Duncker \& Humblot, Berlin, 2005, S. 336. 
već samo okupacione zone. ${ }^{17}$ Uopšte, $\mathrm{u}$ takvom stanju bilo je malo stvari koje bi bile vredne očuvanja.

Podela Nemačke na istočni i zapadni deo značila je i podelu u odnosu prema konzervativizmu. Zvanična komunistička ideologija na istoku gledala je na konzervativizam kao na državnog neprijatelja, budući da je prema ortodoksnom marksističkom tumačenju konzervativizam bio u osnovi isto što i kontrarevolucija odnosno reakcija. Prema zvaničnoj definiciji fašizam je diktatura „najreakcionarniji, najšovinističkijih i najimperijalističkijih elemenata finansijskog kapitala", ${ }^{18}$ čime su konzervativizam i fašizam stavljeni na istu osnovu.

Na zapadu je situacija bila drugačija. Ipak, neposredno posle rata koncepti konzervativno i konzervativizam bili su retko u upotrebi, ${ }_{19}^{19}$ a pojam desnica još ređe u strahu od poistovećivanja sa nacional-socijalizmom. Saveznici, sa svoje strane, nisu imali mnogo poverenja prema domaćoj desnici, i za Nemačku su favorizovali četvoropartijski sistem koji bi uključivao komuniste, socijal-demokrate, liberale i Centar (katolike), tako da nije bilo mesta za desnu, konzervativnu stranku i to iz razumljivih razloga ako se uzmu u obzir interesi Saveznika. ${ }^{20}$ Za osnivanje stranke ili pokretanje novina bile su neophodne savezničke dozvole, te je time konzervativcima bilo dodatno otežano da igraju značajniju ulogu u javnom prostoru. Pod optužbom da su svojim delima prokrčili put za uspon nacional-socijalizma, pojedinim značajnim konzervativcima (Šmit, Jinger, Hajdeger) bilo je zabranjeno da se oglašavaju u javnosti, čime je desnica dodatno oslabljena.

Saveznička politika denacifikacije predstavljala je poseban problem za konzervativce. Naime, čak i oni konzervativci koji nisu imali veze sa

${ }^{17}$ Axel Schildt, "Anpassung und Lernprozesse. Wideraufstieg und Erneuerung des deutschen Konservatismus nach 1945“, in: Michael Großhei, Hans Jörg Hennecke (Hrsg.), Staat und Ordnung im konservativen Denken, Nomos Verlag, Baden-Baden, 2013, S. 191.

${ }^{18}$ Reč je o definiciji koju je dao Georgi Dimitrov 1935. godine na VII kongresu Kominterne. Prema: Sava Živanov, „Doprinos 7. Kongresa KI određenju socijalne prirode fašizma" u: Fašizam i neofašizam, fakultet političkih nauka i Centar društvenih djelatnosti SSOH, Zagreb, 1976, str. 294.

${ }^{19}$ Schildt, "Anpassung und Lernprozesse. Wideraufstieg und Erneuerung des deutschen Konservatismus nach 1945“, S. 191.

${ }^{20}$ Karlheinz Weißmann, Das konservative Minimum, Antaios Verlag, Schnellroda, 2009, S. 66. 
Hitlerovim režimom u savezničkoj politici „prevaspitavanja“ Nemaca videli su pokušaj raskida ne samo sa nacističkom ideologijom, nego i sa nemačkom tradicijom, kulturom, identitetom i povešću. ${ }^{21}$ Prevaspitavanje nije bilo samo pokušaj da se suzbije nacistička indoktrinacija i idejna kontaminacija, već je istovremeno bilo usmereno i protiv klasičnih, konzervativnih tradicija, na koje se gledalo kao na prethodnicu fašizma ili „pra-fašizam“. Tako je za konzervativce politika "prevaspitavanja“ bila više od obračuna sa nacizmom i predstavljala je nasilje protiv nacije, njenih tradicija i nasleđa. Odgovor konzervativaca sastojao se u pokušaju da se pokaže da Hitlerova vlast nije imala nikakve veze sa hrišćanskom, pruskom, konzervativnom tradicijom, već da je nacional-socijalizam idejno bio bliži levičarskim tradicijama, posebno onim iz vremena Francuske revolucije. ${ }^{22}$ Štaviše, konzervativci su smatrali da "prevaspitavanje" zapravo predstavlja amerikanizaciju Nemačke. Ovakvo uverenje nije bilo bez osnova. Okupacione vlasti, nepoverljive prema konzervativcima, nastojale su da ih uklone iz javne sfere ili barem da umanje njihov uticaj, te da na ključna mesta u medijima i univerzitetima dovedu ljude levo-liberalnih nazora. ${ }^{23} \mathrm{U}$ konačnici to je značilo amerikanizovanje ako ne već čitave Nemačke, a ono barem velikog dela nemačke elite. ${ }^{24} \mathrm{U}$ svakom slučaju, amerikanizacija i vesternifikacija Nemačke bila je cena koju su zapadnonemački konzervativci nevoljno plaćali kako bi mogli računati na američku zaštitu od komunističke pretnje. ${ }^{25}$

${ }^{21}$ Vidi: Caspar von Schrenck-Notzing, Charakterwäsche. Die Re-education der Deutschen und ihre bleibenden Auswirkungen, Ares Verlag, Graz, 2015.

${ }^{22}$ Jedan od ranih pokušaja te vrste predstavlja knjiga konzervativnog istoričara Gerharda Ritera. Vidi: Gerhard Ritter, Europa und die Deutsche Frage, Münchener Verlag, Münche, 1948. Takođe, pokušaj rehabilitacije Pruske: Hans Joachim Schoeps, Die Ehre Preussens, Friedrich Vorwerk, Stuttgart, 1951.

${ }^{23}$ Frank-Lothar Kroll, „Die kupierte Alternative, Konservatismus in Deutschland nach 1945" in: Die kupierte Alternative, Konservatismus in Deutschland nach 1945, FrankLothar Kroll (Hrsg), Duncker \& Humblot, Berlin, 2005, S. 12-14.

${ }^{24}$ Da nije u pitanju fikcija konzervativaca svedoči Jirgen Habermas koji u jednom članku konstatuje da bi politička kultura u SR Nemačkoj „,bila u gorem položaju da u prvim desetljećima nakon rata nije preuzela i preradila poticaje iz američke političke kulture." Takođe dodaje da se tada Nemačka "prvi put otvorila Zapadu“ i upoznala „radikalno-demokratski duh američkog pragmatizma“. Nema sumnje da je za Habermasa posleratna amerikanizacija nemačke političke kulture pozitivna stvar. Vidi: Jürgen Habermas, „Kritika kulture kod neokonzervativaca u SAD i SR Njemačkoj" u: Marksizam u svetu, broj 4-5, Beograd, 1983, str. 37.

${ }^{25}$ Kroll, „Die kupierte Alternative, Konservatismus in Deutschland nach 1945“, S. 16. 
S druge strane, upravo je u vreme posle rata SPD pod Kurtom Šumaherom (Kurt Schumacher) bez sumnje bila nacionalnija i od CDU pod Adenauerom i FDP pod Tomasom Delerom (Thomas Dehler). ${ }^{26}$ Upravo je Šumaher optužio Adenauera da je kancelar saveznika u Nemačkoj, što je vrlo podsećalo na optužbu za nacionalnu izdaju i ukazivalo na kolonijalni položaj Nemačke. Prvi put od ujedinjenja 1870, nemački konzervativizam u svom glavnom toku nije bio nacionalan.

Osim politike okupacionih vlasti i drugi, unutrašnji faktori doprineli su marginalizaciji konzervativaca neposredno posle rata. ${ }^{27}$ Pre svega treba imati na umu da su se oblasti koje su tradicionalno važile za uporišta konzervativaca nalazile istočno od Elbe, odnosno da su ostale u sovjetskoj zoni. Svi oni koji su predstavljali otelotvorenje nemačkog puta „između Istoka i Zapada“ ostali su bez svoje "materijalne baze“ ${ }^{28}$

Tako je politička kultura Zapadne Nemačke formirana bez značajnog uticaja „intelektualne desnice ${ }^{\prime 2}{ }^{29}$ To ipak ne znači da takvog uticaja nije bilo uopšte i da u javnu sferu nisu uspeli da se probiju neki ljudi naoružani starim konzervativnim idejama. Hans Cerer (Hans Zehrer) se kao autor jednog „Manifesta desnice“ zalagao za ujedinjenu nemačku monarhiju u starim granicama, dvodomi sistem, slobodnu privredu, kao i za moralnu obnovu nemačke nacije. Poraz nacional-socijalizma Cerer je video kao pobijanje masovne demokratije i kolektivizma protiv kojih se konzervativizam uvek bunio. I bivši logoraš Martin Nimeler (Martin Niemöller) verovao je da demokratija nije za Nemce i umesto nje zahtevao snažno vođstvo sa "pruskim principima“, a nemački istoričar jevrejskog porekla Hans-Joahim Šeps (Hans-Joachim Schoeps) u poznatom govoru iz 1951. godine, ne samo da je tražio ponovno uspostavljanje pruskog carstva, već i nemačke zastave iznad Štetina i Breslaua, Dancinga i Kenigzberga. ${ }^{30}$

${ }^{26}$ Mohler, Von rechts gesehen, S. 45.

${ }^{27}$ Kroll, „Die kupierte Alternative“, S. 7-9.

${ }^{28}$ Alexander Gauland, Anleitung zum Konservativsein. Zur geschichte eines Wortes, Landt Verlag, Berlin, 2017, S. 39.

${ }^{29}$ Kroll, ,"Die kupierte Alternative“, S. 3. Početkom šezdesetih godina su mediji gotovo preko noći postali "closed shop" levih liberala. Caspar von Schrenck-Notzing, Konservative Publizistik. Texte aus den Jahren 1961 bis 2008, Föderstiftung konservative Bildung und Forschung, Berlin, 2011, S. 251.

${ }^{30}$ Weißmann, Kurze Geschichte der konservativen Intiligenz, S. 20-24. Schoeps, Die Ehre Preussens. 
Od 1946. primetno je bilo i jačanje crkava, a prevashodno katoličkokonzervativne linije oko časopisa Neues Abendland, oko koga će od 1949. delovati i akademija (Abendländlische Akademie), prva u pravom smislu reči konzervativna kulturna ustanova posle rata. ${ }^{31}$ Ideal ovog kruga bili su antikomunistički, hrišćanski režimi poput onih u Španiji i Portugaliji. Istovremeno i protestantske zajednice su pedesetih još negovale pozitivan odnos prema pojmu nacije. Za mnoge se tada još uvek podrazumevalo da je konzervativno isto što i hrišćansko. Mnogo godina kasnije Kaspar fon Šernk-Nocing (Caspar von Schrenck-Notzing) će kazati da je „Adenauerova era" predstavljala period nemačke istorije koji je možda najviše bio oblikovan konzervativizmom. ${ }^{32}$

Ipak, mora se naglasiti da su konzervativni krugovi već od prvih dana bili daleko od bilo kakve homogenosti. Luk se protezao od katoličkih konzervativaca poput Kinelt-Ledina i Emila Francela (Emil Franzel), preko pruskih poput Šepsa, liberalno konzervativnih poput Hans-Joahima fon Merkaca (Hans Joachim von Merkatz), do „konzervativnih tehnokarata“ poput Hansa Frajera (Hans Freyer), Ernsta Forsthofa (Ernst Forsthoff) i Arnolda Gelena (Arnold Gehlen). ${ }^{33} \mathrm{Ne}$ treba imati iluzija da je u okviru ovih "fragmenata desnice" (Armin Moler) vladala harmonija, već je i u okviru tog kruga dolazilo do sukoba, na primer između katoličkih i nacionalnih konzervativaca. ${ }^{34}$

Organizacioni izraz konzervativizma u ranom periodu SR Nemačke bila je Nemačka stranka (Deutsche Partei). Bila je to , jedina posleratna stranka koja je postavila pojam 'konzervativno' u centar svoje programatike“.${ }^{35}$ Stranka je

${ }^{31}$ Weißmann, Kurze Geschichte der konservativen Intiligenz, S. 22. Misao ovog kruga poticala je od ideja kasne političke romantike i suprotstavljala se s jedne strane nacionalizmu, a s druge kosmopolitizmu, dok se pre svega borila protiv prosvetiteljskog sekularizma. Većina stranka na vlasti smatrala je duhovnu pomoć na "hrišćansko-konzervativnoj bazi“ dobrodošlom. Schrenck-Notzing, Konservative Publizistik, S. 255-256.

${ }^{32}$ Schrenck-Notzing, Konservative Publizistik, S. 250-251.

${ }^{33}$ Kroll, „Die kupierte Alternative“, S. 3-4. Naravno, prisutne su i drugačije podele na primer: Mohler, Von rechts gesehen, S. 43-54.

${ }^{34}$ Vidi: Armin Mohler, Tendenzwende für Fortgeschrittene, Criticon Verlag, München, 1978, S. 20-21.

${ }^{35}$ Sven-Uwe Schmitz, Konservativismus, VS Verlag für Sozialwissenschaften, Wiesbaden, 2009, S, 159, 129. 
nastala od Donjosaksonske zemaljske partije, a na temelju velfske tradicije, da bi ubrzo (1947) promenila ime i proširila se i na ostale pokrajne. Nakon prvih izbora za Bundestag (1949) DP je ušla u koalicionu vladu sa CDU/CSU. Ipak, iako joj je cilj bio okupljanje snaga desno od CDU, odnosno svih konzervativnih snaga bez obzira da li su bile hrišćansko, liberalno ili nacionalkonzervativne, DP nije uspela da se jasno profiliše. Svakako, konzervativizam, federalizam, antikomunizam i država bazirana na profesionalnom činovništvu bile su zajedničke tačke, ali je pored toga bilo dosta spornih pitanja, kao što su bile tenzije između nacionalista i monarhista. ${ }^{36}$ Po privrednim pitanjima, stranka je bila bliska FDP, dok je po kulturnim pitanjima bila uz CDU zalažući se za hrišćanske škole. Međutim, DPje odbila da podrži usvajanje bonskog Osnovnog zakona zbog toga što nije davao dovoljno garancija protiv moguće državne intervencije u privredi i protiv težnji za preoblikovanjem društva, ${ }^{37}$ a u okviru stranke postojali su sporovi o simboličkim pitanjima, odnosno pitanju izgleda nemačke zastave. DP je imala razvijene veze sa organizacijama nemačkih izbeglica iz Istočne Evrope i od početka je bila suprotstavljena denacifikaciji, te zastupala interese bivših pripadnika Vermahta. ${ }^{38} \mathrm{U}$ svojim zahtevima DP je tražila ujedinjenje Nemačke u njenim predratnim granicama, koje ne samo da su uključivale Istočnu Nemačku, nego i teritorije koje su posle rata pripojeneSSSR-u, Poljskoj i Čehoslovačkoj. Ipak, u ono vreme to se nije smatralo ničim radikalnim, pa je čak i CDU preko predizbornih plakata obećavala ujedinjenje čitave otadžbine. Tokom godina DP je postajala sve više zavisna od CDU kao snažnijeg partnera, da bi naposletku ministri i poslanici napustili DP i priključili se CDU. Stranka je 1960. godine napustila vladu i praktično ne postoji od 1961. godine. Međutim, dok je postojala DP je bila lokalna stranka koja nije mogla računati na snažniju podršku osim na severu, odnosno u svom uporištu u Donjoj Saksoniji gde je osvajala oko 19\% glasova. Na saveznim izborima DP nije uspevala da osvoji više od $4 \%$ glasova. Nestanak nemačke stranke značio je uspostavljanje „,asimetričnog partijskog spektra“ (Franc Jozef Štraus) koji se bez protivteže sa desnice nužno pomera sve više ulevo. ${ }^{39}$

\footnotetext{
${ }^{36}$ Karlheinz Weißmann, Armin Mohler. Eine politische Biographie, Antaios Verlag, Schnellroda, 2011, S. 122.

${ }^{37}$ Ludwig Bergsträsser, Geschichte der politischen Parteien in Deutschland, Isar Verlag, München 1952, S. 288.

${ }^{38}$ Ibid.

${ }^{39}$ Schrenck-Notzing, Konservative Publizistik, S. 253.
} 
Nestankom DP nemački konzervativizam je ostao bez političke prave domovine. Nije dakle čudno kada pojedini istraživači, možda suviše ishitreno, tvrde da je nemački konzervativizam posle pedesetih ušao $u$ „fazu beznačajnosti“ ${ }^{40}$ Iako su kasnih četrdesetih i ranih pedesetih godina hrišćanski intelektualci mogli računati na široku publiku, kasnih pedesetih hrišćanska renesansa bila je završena. ${ }^{41}$ Godine 1958. prestao je da izlazi i časopis Neues Abendland koji je bio najvažniji organ katoličkih konzervativaca i koji je pokušavao da na osnovu katoličkog socijalnog učenja formira alternativu kako socijalističkoj uranilovci, tako i angloameričkom liberalizmu. Kako piše Šrenk-Nocing, obustavljanje časopisa i akademije katoličkih konzervativaca i gašenje DP "nisu bili netipični“, naprotiv, posle 1958. temeljno se promenila "čitava duhovna klima“. ${ }^{42} \mathrm{U}$ izvesnom smislu, konzervativizam Adenauerove ere bio je žrtva sopstvenog uspeha. Unutrašnja stabilizacija države, brza obnova zemlje i snažan skok kvaliteta života i blagostanja bili su novi izazov za hrišćanski konzervativizam. Njegov antimodernizam i skepsa prema masovnom društvu delovali su zastarelo i prevaziđeno, a hedonizam i konzumerizam bogatog društva podrivali su konzervativne vrednosti. Prema ŠrenkNocingu, to je značio kraj konzervativizma Adenauerovog vremena, ali istovremeno se šezdesetih i sedamdesetih godina pod pritiskom položaja obrazovao jedan novi konzervativizam. ${ }^{43}$ U vreme studentske pobune 1968, posred nove levice, začeta je i nova desnica.

Naravno, gašenje DP i potiskivanje katoličkog konzervativizma ne znači da nije bilo lokalnih inicijativa i pokušaja da se formira neka konzervativna stranka, ali su svi ti pokušaji ostali manje ili više neuspešni. Sa druge strane, marginalne desne stranke poput NPD (Nationaldemokratische Partei Deutschlands) nisu bile u stanju da naprave distancu od nacional-socijalizma, čime su gubile svaku vezu sa konzervativnim taborom, te ostajale izolovane i marginalizovane.

\footnotetext{
${ }^{40}$ Schmitz, Konservativismus, S. 159.

${ }^{41}$ Dirk Van Laak, "From the Conservative Revolution to Technocratic Conservatism" in: German Ideologies since 1945, Jan-Werner Muller (ed.), Palgrave Macmillan, London, p. 152.

${ }^{42}$ Schrenck-Notzing, Konservative Publizistik, S. 256.

${ }^{43}$ Ibid., S. 257.
} 
Od 1961. godine u Bundestagu su bile zastupljene samo tri frakcije (CDU/CSU, FDP i SPD), čime je CDU praktično bila stranka bez konkurencije na desnici. To je Uniju dovelo u udobnu poziciju da se bez bojazni za svoje konzervativne birače, bori za glasove sa liberalima i socijaldemokratama. Pojedini istraživači veruju da je CDU pedesetih sistematski nastojala da neutrališe svu opoziciju zdesna. ${ }^{44}$

Tokom pedesetih godina došlo je i do pokušaja da se liberalna FDP, koja je i pre toga u poslaničkim klupama bila smeštena desno od CDU, ${ }^{45}$ reformiše u neku vrstu nacionalno-liberalne stranke, ali je ta inicijativa ostala bez uspeha, da bi posle 1954. i koalicije FDP i SPD desna struja u stranci bila marginalizovana.

Iako je od šezdesetih godina nemački konzervativizam ostao ograničen samo na CDU/CSU, taj odnos bio je daleko od jednostavnog. Istina, CDU je od početka bila više od naslednika stranke Centra i jedan pokret koji je, iako je uključivao i politički katolicizam, ipak uspeo da prikupi i značajne delove građanstva i seljaštva, čak i protestante ili one koji nisu mnogo polagali na religiju. ${ }^{46} \mathrm{U}$ odnosu na Centar, CDU je bila nešto malo više desno, ali još uvek stranka koja je mogla da sklapa političke veze i sa levicom i sa desnicom. ${ }^{47}$ Bez druge realne alternative deo konzervativaca podržavao je CDU, čak i kada nije bio sasvim zadovoljan stranačkom politikom..$^{48}$ Ipak, uprkos tome što su konzervativci u njoj igrali izvesnu ulogu, CDU nikada nije želela da bude stvarno konzervativna stranka, nego je od početka bila "omnibus partija centra" (Šrenk-Nocing) ${ }^{49}$ To je značilo da u stranci može biti mesta za konzervativce, ali samo kao jednu od struja. Prema Gaulandu (Alexander Gauland), CDU je bila stranka modernizacije koja je trebalo da "dovrši projekat moderne i utvrdi demokratsko industrijsko društvo u Nemačkoj", a konzervativna je samo utoliko koliko želi da očuva poredak koji je u Zapadnoj Nemačkoj nastao nakon 1949, a to je poredak

\footnotetext{
${ }^{44}$ Schmitz, Konservativismus, S. 139.

${ }^{45}$ Bergsträsser, Geschichte der politischen Parteien in Deutschland, S. 286.

${ }^{46}$ Weißmann, Das konservative Minimum, S. 66.

${ }^{47}$ Bergsträsser, Geschichte der politischen Parteien in Deutschland, S. 279-280.

${ }^{48}$ Prema Moleru, CDU je bila stranka rođena u nemačkom porazu što je uticalo na kasniji život stranke. Nakon Adenauerove smrti postalo je vidljivo koliko malo nacionalne samosvesti se nalazi u CDU. Mohler, Tendenzwende für Fortgeschrittene, S. 22.

${ }^{49}$ Weißmann, Das konservative Minimum, S. 65.
} 
demokratskog industrijskog društva, čija „klasna struktura je slabije razvijena nego kod klasičnih demokratija" ${ }^{50}$ Izbegavajući da se postavi kao fundamentalna opozicija levici, CDU od sedamdesetih godina sebe definiše kao „socijalnu, narodnu stranku centra“. Već tada stranka ne raspolaže koherentnom doktrinom, već samo neobavezujućim i opštim lozinkama (antikomunizam, socijalno-tržišna privreda). U to vreme konzervativni publicista Gerd-Klaus Kaltenbruner (Gerd-Klaus Kaltenbrunner) konstatuje činjenicu, da na nemačkom govornom prostoru nema konzervativne stranke i da je konzervativac u opasnosti da "protiv sebe ima sve partije. ${ }^{\prime 51}$ Armin Moler (Armin Mohler) je išao dalje, tvrdeći da od kraja rata u Nemačkoj nema desnice vredne pomena, ${ }^{52}$ dok je u jednom docnijem tekstu nastojao da opovrgne "predrasudu“ da je CDU konzervativcima "po prirodi bliža nego SPD“, tvrdeći da je to stvar "određene političke situacije" ${ }^{53}$ Nemajući takmaca sa desne strane, CDU je bila u poziciji da monopolizuje glasove konzervativaca, te da počne da se pomera dalje prema levici, što je proces koji je otpočeo još krajem pedesetih godina. U svom odgovoru na jedan Molerov tekst, to je potvrdio i sociolog Robert Hep (Robert Hepp) rečima da se stranka nije morala brinuti za svoje desno krilo, već da se mogla koncentrisati na koncesije koje je u nevolji morala činiti svojim „socijalnim odborima i potencijalnim liberalnim biračima“. U istom tekstu, Hep kaže, da je konzervativno glasačko telo bilo zadovoljno time što se CDU verbalno i pro forma protivilo reformama, dok je verbalni radikalizam Dregera (Alfred Dregger) i Štrausa (Franz-Josef Strauss) bio samo "sredstvo u izbornoj borbi“ ${ }^{\prime 5}$ Nezadovoljni politikom CDU konzervativci poput Molera su, s vremena na vreme, isticali potrebu da CSU pređe granice Bavarske i postane "četvrta stranka“, ali stranačko vođstvo nije bilo spremno na takav korak.

SR Nemačka je tokom šezdesetih godina bila svedok jačanja levog ekstremizma i terorizma. „Pojedinačni slučajevi nasilja, pretnji i zastrašivanja profesora na nemačkim univerzitetima od strane grupa

\footnotetext{
${ }^{50}$ Gauland, Anleitung zum Konservativsein, S. 34-35.

${ }^{51}$ Gerd-Klaus Kaltenbrunner, Der schwierige Konservatismus. Definitionen, Theorien, Porträts, Nicolaische Verlagsbuchhandlung, Herford, Berlin, 1975, S. 116.

${ }^{52}$ Mohler, Von rechts gesehen, S. 42.

${ }^{53}$ Mohler, Tendenzwende für Fortgeschrittene, S. 15-22.

${ }^{54}$ Ibid., S. 25.
} 
radikalne levice počeli su kasnih šezdesetih i intenzivirani su ranih sedamdesetih. " 55 Nasilje ipak nije ostalo ograničeno na univerzitete. Međutim, uprkos rastu levičarskog nasilja, od 1964. nijedna levičarska organizacija u Nemačkoj nije zabranjena kao ekstremistička. ${ }^{56}$ Takođe, studentska pobuna 1968. bila je delom rezultat posleratnog prevaspitavanja. Nakon studentske pobune, levica započinje svoj „dugi marš kroz institucije“ s ciljem da sistem obori iznutra. ${ }^{57}$ Jačanje levice zahvata i crkve, prvo protestantske, a potom i katoličku, posebno posle Drugog vatikanskog koncila, čime je formula prema kojoj je hrišćansko jednako konzervativno dovedena u pitanje, a pozicija konzervativaca dodatno oslabljena. Zapravo, još od pedesetih godina su pojedinačni konzervativci dijagnostikovali da su crkve postale najvažniji rezervoari levih impulsa. ${ }^{58}$ Sve je to ukazivalo na snažnije pomeranje nemačkog društva ka levici, dok su konzervativci gubili podršku u institucijama.

Suočeni sa krizom šezdesetih godina, konzervativci pokušavaju da se konsoliduju i da povrate inicijativu. Tako se od šezdesetih godina sve glasnije govori o "promeni tendencije“ (Tendenzwende), ali akcija je bila malo ili nimalo uspešna. Svi pokušaji da se formira aktivna desnica pokazali su se jalovim. Zapravo, levica je odnela pobedu u izdavačkim i medijskim kućama, ${ }^{59}$ kao i na univerzitetima. ${ }^{60}$ Štaviše, prema Moleru, još pre studentske pobune „levica je u državi i društvu Savezne republike postala

${ }^{55}$ Jerry Z. Muller, „German Neo-Conservatism, ca. 1968-1985: Hermann Lübbe and Others" in: German Ideologies since 1945, Jan-Werner Muller (ed.), Palgrave Macmillan, London, p. 166.

${ }^{56}$ Steffen Kailitz, Politischer Extremismus in der Bundesrepublik Deutschland. Eine Einführung, VS Verlag für Sozialwissenschaften, Wiesbaden, 2004, S. 220 Pa ipak, uprkos ovom popustljivom stavu prema ekstremizmu sa levice, nemačka levica je nastavila da se žali na "lov na ustavne neprijatelje", teror i "sektorski fašizam" u Zapadnoj Nemačkoj. Manfred Clemenz, „Prilog fenomenologiji fašizma“ u: Fašizam i neofašizam, Fakultet političkih nauka i Centar društvenih djelatnosti SSOH, Zagreb, 1976, str. 24-27.

${ }^{57}$ Helmut Schelsky, Systemüberwindung, Demokratisierung, und Gewaltteilung. Grundsatzkonflikte der Bundesrepublik, C. H. Beck, München, 1974, S. 19-37.

${ }^{58}$ Mohler, Von rechts gesehen, S. 55.

${ }^{59}$ Već krajem šezdesetih godina opaža se da i ugledni Frankfurter Allgemeine Zeitung $\mathrm{u}$ svom feljtonu koji je nekada vodio Fridrih Ziburg (Friedrich Siburg), odustaje od svoje politike i klizi ka levici. Ibid., S. 279-283.

${ }^{60}$ Muller, „,German Neo-Conservatism, ca. 1968-1985“, pp. 166-167. 
institucija, jer je ispunjavala funkcije koje drugi nisu želeli - ili mogli - da ispune. " ${ }^{11}$ Konzervativci su gubili čak i ono što su do tada posedovali. Tako su šezdesete godine bile efektivna faza u vesternizaciji Nemačke. ${ }^{62}$ Istovremeno, to je bilo vreme proboja "nove levice“ kao i promene slike o konzervativizamu. Naime, nemačka konzervativna tradicija se sve više shvata kao reakcionarna priprema za nacional-socijalizam $\mathrm{u}$ kontekstu teorije o "posebnom putu“ (Sonderweg) koja je $\mathrm{u}$ to vreme postala dominantna u Zapadnoj Nemačkoj, a prema kojoj je nacional-socijalizam logična posledica nemačkog odvajanja od Zapadnog puta u modernost koji je počeo, u najmanju ruku, još sa Luterom. ${ }^{63}$ Time je nemačka tradicija konzervativizma interpretirana kao nešto po sebi pogrešno i zlo. ${ }^{64}$ Ipak, šezdesetih godina je CDU još uvek imala dovoljno snage da se na predizbornim plakatima predstavlja kao snaga odbrane Zapada (Abendland). Naravno, u kontekstu Hladnog rata to se odnosilo na odbranu Zapada od boljševizma, ali je značajno da se tada još uvek u okviru te stranke podrazumevalo da postoji nešto što se naziva Zapad, odnosno da postoji posebna Zapadna, hrišćanska kultura, te da je ona vredna da bude predmet odbrane, dok današnja CDU izričito osuđuje takve stavove. ${ }^{65} \mathrm{U}$ svakom slučaju, šezdesetih godina CDU je sebe videla kao narodnu stranku odnosno stranku centra u kojoj postoje različiti elementi uključujući liberalne, socijalne i naposletku konzervativne. ${ }^{66}$ Ipak, konzervativizam je bio samo jedan među elementima, i to ne onaj najvažniji. Kurt Georg Kizinger (Kurt Georg Kiesinger) kao šef stranke odbio je da CDU okarakteriše

${ }^{61}$ Armin Mohler, Was die Deutsche fürchten, Seewald Verlag, Stuttgart-Degerloch, 1965, S. 212. Jačanje levice dakle, prema Moleru nije bio ni plod zavere, niti nesrećnog sticaja okolnosti.

${ }^{62}$ Kroll, "Die kupierte Alternative“, S. 19.

${ }^{63} \mathrm{O}$ naučnoj neutemeljenosti ove teze, kao i o njenom ideološkom aspektu, odnosno političkoj upotrebi vidi: Panajotis Kondylis, "Die deutsche 'Sonderweg' und die deutschen Perspektiven" in: Panajotis Kondylis, Das Politische im 20. Jahrhundert: Von den Utopien zur Globalisierung, Manutius Verlag, Heidelberg, 2001, S, 161-180.

${ }^{64}$ Ovo shvatanje opstaje i u pomenutom Zočekovom članku, gde autor kaže da su u tokom dvadesetih i tridesetih godina konzervativci držali merdevine fašizmu. Sotscheck, "Nicht naiv Testballons jagen".

${ }^{65}$ Nekoliko decenija kasnije, kada u Drezdenu budu protestvovali građani zabrinuti zbog islamizacije Zapada, političari CDU će u njima videti samo mržnju i predrasude (Angela Merkel).

${ }^{66}$ Schmitz, Konservativismus, S. 141-142. 
kao konzervativnu partiju, što je izjava koju je sa mesta prvog čoveka stranke ponovio i Helmut Kol (Helmut Kohl). Čak je i za njega CDU bila stranka centra.

Koliko se nemačko društvo pomerilo ka levici postalo je očevidno osamdesetih godina tokom rasprave istoričara (Historikerstreit). Tada su na videlo izašle dve pojave. Prvo, da je četrdeset godina posle rata senka nacional-socijalizma postala i duža i tamnija nego što je to bio slučaj neposredno nakon rata. Što je rat ostajao dublje u prošlosti, o njemu se teže moglo trezveno razgovarati, optužba za fašizam bila je sve teža, sve češće se koristila i to sa sve težim posledicama. Drugo, pokazalo se u kojoj meri je akademski svet pao pod dominaciju levice, te da je ta prevlast uzela oblik isključenja svih koji zastupaju neko drugačije stanovište. Zapravo, postalo je jasno da su antitotalitarni konsenzus i ekvidistanca prema ekstremnoj desnici i levici zamenjeni antifašističkim konsenzusom koji na meti ima samo desnicu (ne nužno samo ekstremnu) dok ekstremnu levicu potpuno gubi iz vida.

Istovremeno, osamdesetih godina dolazi do još jednog pokušaja da se formira stranka desno od CDU/CSU. Inicijativa je došla od strane razočaranih konzervativaca. Zapravo, desno krilo CDU/CSU bilo je sve nezadovoljnije, a razlozi tom nezadovoljstvu ležali su u politici evropskih integracija i prihvatanju istočne politike (Ostpolitik). Konačno, kada je 1983. godine lider CSU Štraus podržao odobravanje kredita Istočnoj Nemačkoj u iznosu od više od 10 milijardi maraka, bila je to velika promena u nemačkoj politici, pa stoga i okidač za rascep u CSU. Nekoliko poslanika, među kojima i Franc Handlos (Franz Handlos) i Ekehart Foigt (Ekkehard Voigt) napustili su stranku i zajedno sa televizijskim voditeljem Francom Šenhuberom (Franz Schönhuber) osnovali Republikance (Die Republikaner). Stranka je tokom osamdesetih i devedesetih ostvarila izvesne uspehe, uglavnom zahvaljujući „narodnom tribunu“ Šenhuberu, koji je uspeo da za savetnike pridobije i neke od istaknutih konzervativnih intelektualaca ${ }^{67}$ (Armin Moler, Robert Hep, Helmut Divald). Na izborima za Evropski parlament, Republikanci su osvojili $7,1 \%$ glasova, a glavne teme su bile imigracija i unutrašnja bezbednost. Slično DP, Republikanci su nemačko ujedinjenje videli kao svoj najvažniji cilj. Ujedinjenje iz 1990. godine shvaćeno je samo kao prvi korak ka punom ujedinjenju Nemačke u međunarodno priznatim granicama iz

${ }^{67}$ Weißmann, Kurze Geschichte der konservativen Intiligenz, S. 67. 
1937. godine. U svojoj ekonomskoj politici Republikanci su bili vrlo bliski klasičnim liberalnim pozicijama. Pored toga, stranka je zahtevala kraj politike prevaspitavanja, što je bio stari konzervativni zahtev. Uprkos pojedinim uspesima, Republikanci nisu uspeli da uđu u Bundestag i posle više internih razmimoilaženja, usled "nedostatka jasne ideologije ${ }^{\text {“68 }}$ te izolacije od strane ostalih partija, stranka je izgubila snagu. Već su Republikanci okarakterisani kao „desno-populistička stranka“ ${ }^{69} \mathrm{U}$ svakom slučaju, osamdesete su značile promenu unutar nemačkog konzervativizma i preuzimanje novih tema kao što su naglašavanje nacionalnog identiteta, kritika multikulturalizma, snažna država, ujedinjenje i centralno-evropska politika umesto vezivanja za Zapad.

Uprkos činjenici da se nemački konzervativizam tokom osamdesetih i devedesetih ",ponovo nalazio u dubokoj krizi“ ${ }^{70}{ }^{7}$ već se osamdesetih sve više govori o ,jačanju desnice“. Nema sumnje da je nemačko ujedinjenje dalo podstrek rastu konzervativizma i nacionalizma, posebno na istoku zemlje. Ipak, to je manje ili više bio slučaj i u ostalim državama koje su bile pod komunizmom. Delovalo je da su antikomunisti i konzervativci sve vreme bili u pravu i da je komunizam od početka bio osuđen na neuspeh. Izgledalo je da je levica izgubila na zamahu i da su konzervativci ugrabili šansu, a nije bilo malo onih koji su pokušavali da iskoriste nacionalno oduševljenje. U vreme kada su Nemci, pre svega na istoku, protestovali protiv imigranata sve stranke, osim Zelenih, bile su zabrinute zbog pojačane imigracije. Slično ostalim istočno-evropskim zemljama i u Nemačkoj su se formirale pojedine ekstremno desne grupe, ali uglavnom marginalne i neuspešne, a radikalna desnica je i tada bila daleko od mesta u Bundestagu. Sa druge strane, konzervativno opredeljene glasače na istoku uspešno je preuzela CDU.

Ipak, konzervativci nisu uspeli da iskoriste okolnosti i levica se vrlo brzo reorganizovala. Pokazalo se da su na planu privrednog poretka konzervativci i liberali odneli pobedu u Hladnom ratu, ali da je levica pobedila na univerzitetima i u medijima te tako uspostavila kulturnu hegemoniju, što se odražavalo i na stranački život. Tako je pod Kolom CDU

\footnotetext{
${ }^{68}$ Weißmann, Armin Mohler, S. 227.

${ }^{69}$ Alexander Häusler, Mut zur Wahrheit? Entstehungskontext, Entwicklung und gesellschaftspolitische Positionen der "Alternative für Deutschland“", FORENA, Düsseldorf, 2014, S. 17.

${ }^{70}$ Schrenck-Notzing, Konservative Publizistik, S. 263.
} 
dodatno dovela u pitanje svoj konzervativni identitet $i$ još više se približila SPD-u, što je postalo jasno još u vreme rasprave istoričara. Doduše, Kol jeste govorio o duhovno-moralnoj promeni, što je nalikovalo starim konzervativnih zahtevima za promenom tendencije koji su išli za tim da se zaustavi trend eksperimentisanja i stalnog reformisanja društva koji je nastupio posle studentske pobune, odnosno da se uspostavi kopča sa onim tradicijama koje su omogućile posleratnu obnovu. Međutim, Genšer (HansDietrich Genscher) je svoj zadatak video upravo u tome da spreči "konzervativnu kontrareformaciju“ ${ }^{71}$ Kako kaže Gauland, Kol je najavio duhovno-moralni zaokret, ali to nije bilo više od obećanja da će praviti manje dugova. ${ }^{72}$ Takođe, umesto promenama u društvu Kol je pristupio modernizaciji svoje stranke, što je značilo kidanje preostalih veza sa konzervativnim nasleđem stranke, te preuzimanje "mekih tema“ (ženska i socijalna pitanja, ekologija). ${ }^{73}$ Već tada se na vrednosnom nivou CDU jedva mogla razlikovati od levice i tačke sporenja svodile su se jedino na pitanju strategija i brzine reformi. Nemoć konzervativnog krila u CDU pokazala se jasno 1980. kada je konačno propao pokušaj pobune protiv Kola i sekretara Hajnera Gajslera (Heiner Geißler). Čak ni posle ujedinjenja konzervativci nisu imali većeg uticaja na donošenje političkih odluka. Umesto spoljne politike vođene nacionalnim interesima formiranja nove i nezavisne spoljne politike, ujedinjena Nemačka je velikim delom brzo predala svoj nacionalni suverenitet u Mastrihtu i Amsterdamu..$^{74}$ Istovremeno, zemlja se suočava i sa sve brojnijom imigracijom. Ovo odustajanje od koncepta nacionalne države dolazilo je iz same CDU. Gajsler je tvrdio da je Nemačka „ostvarila velike uspehe u ekonomiji, socijalnoj i spoljnoj politici ne kao klasična nacijadržava, već pre kao demokratska, kosmopolitska i evropski orijentisana zemlja. ${ }^{75}$ On je u svojim zahtevima išao toliko daleko, da je 1989. godine radio na tome da se iz programa stranke izbaci deo o nemačkom ujedinjenju. ${ }^{76}$ Do toga nije došlo, a Kol je uspeo da ujedinjenje uknjiži kao

\footnotetext{
${ }^{71}$ Ibid., S. 262.

${ }^{72}$ Gauland, Anleitung zum Konservativsein, S. 93.

${ }^{73}$ Weißmann, Kurze Geschichte der konservativen Intiligenz, S. 64; Weißmann, Das konservative Minimum, S. 72.

${ }^{74}$ Winckler, "Konservative Intelligenz in vereinigten Deutschland", S. 328.

${ }^{75}$ Heiner Geißler, Der Irrweg des Nationalismus, Beltz Athenäum, Weinhem, 1995, S. 9.

${ }^{76}$ Weißmann, Das konservative Minimum, S. 74.
} 
svoj uspeh. Takođe, od devedesetih godina CDU postaje sve aktivnija u inicijativama protiv desnice, kao i na protestima protiv nacionalističkih skupova. Na taj način CDU se već tada našla u istom frontu ne samo sa socijal-demokratama i zelenima, nego i sa snagama ekstremne levice.

Ipak, tokom devedesetih konzervativni intelektualci, tzv. "nova demokratska desnica", kritikovali su politiku evropskih integracija, preveliku vezanost za Zapad, političku klasu kao i multikulturalistički projekat, ${ }^{77}$ što znači da su ključna pitanja koja danas pokreće Alternativa za Nemačku (AfD) u intelektualnim krugovima razmatrana pre formiranja te stranke. Zapravo, sredinom devedesetih bi, prema anketama, jedna demokratska desna stranka mogla računati sa $15-20 \%$ podrške. ${ }^{78}$ Ipak, uprkos očekivanjima intelektualaca iz ove grupe, nije došlo do „povratka u istoriju“ (Vajsman), niti je ujedinjena Nemačka postala istočnija, pruskija, protestantskija, konzervativnija i nacionalnija.

Početkom XXI stoleća, Nemačka se nalazi u čudnovatoj poziciji. Površno posmatrano, to je zemlja koja odaje sliku snage, ekonomskog prosperiteta, visokog životnog standarda, stabilnog političkog i pravnog sistema. Sa druge strane, veliki broj Nemaca je govorio da im nemačko poreklo stvara izvesnu nelagodu, osim $u$ vreme prvenstva $u$ fudbalu. U bogatoj zemlji samo-mržnja i "nacional mazohizam“ (Moler) postali su deo svakodnevnog govora, a nemačka omladina išla je na demonstracije pod parolama „Nikada više Nemačka" (Nie wieder Deutschland, Deutschland verrecke). Nije teško uspostaviti vezu između ovih parola i posleratnog prevaspitavanja, ili barem dominacije levice na univerzitetima počev od šezdesetih godina. $U$ slučaju mlađih naraštaja, antifašizam je prerastao u antinemstvo. ${ }^{79}$

${ }^{77}$ Najznačajniji dokumenti ove grupe su zbornici: Rainer Zitelmann, Kralheinz Weissmann, Michael Grossheim (Hrsg.), Westbindung. Chancen und Risiken für Deutschland, Propyläen, Frankfurt am Main, Berlin, 1993; Heimo Schwilk, Ulrich Schacht (Hrsg.), Die selbstbewusste Nation: "Anschwellender Bocksgesang" und weitere Beiträge zu einer deutschen Debatte, Ullstein, Berlin, 1994.

${ }^{78}$ Schrenck-Notzing, Konservative Publizistik, S. 267.

79 „Nakon iskustava diktature, rata i poraza, samomržnja u kulturnom smislu dobila je novi kvalitet. Nacionalsocijalizam je kao oblik agresije i proizvod nihilizma bio pokušaj da se njena energija usmeri prema spolja posredstvom imperijalizma i rata. Deca ovog neuspelog poduhvata i istorijski poraženi krenuli su upravo suprotnim putem. Oni su osuđivali imperijalizam i rat s istom odlučnošću s kojom su prethodno bili vođeni, usmerili su energiju kulturne samomržnje opet isključivo ka unutra. Time je fenomen koji je dugo bio ispod praga svesti i delovao kao sporadična nelagoda postao očevidan. 
Ipak, to nisu jedini glasovi koji se mogu čuti. Sven-Uve Šmic (Sven-Uwe Schmitz) veruje da još uvek postoji mesto za konzervativizam, ili kako je pisao Cicero magazin: "Zeitgeist je konzervativan“. ${ }^{80}$ Rođena je nova, samouverena generacija, koja otvoreno kaže da je sumnjičava prema levičarskoj slici sveta i šezdesetosmaškim obećanjima, da je umorna od stalnih emancipatorskih eksperimenata, da je konzervativna, te da je nezadovoljna situacijom u svojoj zemlji. Dakle, moguće je govoriti o promeni mentaliteta. ${ }^{81}$ Nove generacije su patriotski orijentisane, zainteresovane za religiju, sa pozitivnim odnosom prema tržištu. Ipak, taj novi konzervativizam bio je nepolitički i u izvesnoj meri naivan. Međutim, ubrzo je postalo jasno da CDU nije u stanju da na ovu promenu pruži odgovor, odnosno da socijaldemokratizovana Unija nije u mogućnosti da za sebe veže novi naraštaj, te da nema šta da mu ponudi.

Kada je Tilo Saracin (Thilo Sarrazinn), bivši finansijski senator Berlina i tada još uvek član SPD, objavio knjigu u kojoj je tvrdio da Nemačka uništava samu sebe, ${ }^{82}$ ona je izazvala ogromnu pažnju širom Evrope. Za 18 meseci knjiga je imala više od 20 izdanja. Saracina i njegove izazivačke teze o masovnom useljavanju i multikulturalnom društvu nije bilo moguće ignorisati. Prema istraživanjima javnog mnjenja iz septembra 2010. godine, fiktivna Saracinova stranka mogla je računati na $18 \%$ glasova. ${ }^{83}$ Zanimljivo

Dalje, pokazalo se - ništa manje jasno, ali jedva primećeno - koliko i do koje mere su takozvani šezdesetosmaši prema svojoj duhovnoj osnovi bili ono što nikada nisu želeli da budu, naime reakcija na neuspeh nacionalsocijalizma. Oni zapravo nisu predstavljali nikakav delotvoran protivpokret, već njegov nastavak, samo u suprotnom smeru. Umesto želje za osvajanjem i rasnog fanatizma nastupilo je totalno odricanje od vlasti i moći (bar prema spolja), namesto glajhšaltovanja stupila je nivelacija, a mržnju prema tuđem zamenila je mržnja prema svome. Svako kvalitativno razlikovanje smatra se mrljom, usled čega se mora ukloniti. Nekadašnji vladalac i glavni „zločinac“ u istoriji počinje se identifikovati sa „žrtvama“. Noseći tip ovog jednako izvorno totalitarnog pokreta obrazovao je pervertovani oblik onoga iz čega je i proizašao. Tako se paradoks po sebi totalitarno motivisanog "antifašizma“ pretvorio u novu nemačku državnu doktrinu." Frank Lisson, Die Verachtung des Eigenen, Über den kulturellen Selbsthaß in Europa, Antaios Verlag, Schnellroda, 2019, S. 22-23.

${ }^{80}$ Schmitz, Konservativismus, S. 166-170.

${ }^{81}$ Weißmann, Das konservative Minimum, 16-18; Weißmann, Kurze Geschichte der konservativen Intiligenz, S. 9-12.

${ }^{82}$ Thilo Sarrazinn, Deutschland schafft sich ab, Deutsche Verlags-Anstalt, München, 2010.

${ }^{83}$ Häusler, Mut zur Wahrheit?, S. 29. 
je da Saracin nije čovek sa desnice, niti je u strogom smislu konzervativan. On je socijal-demokrata, javni službenik i član izvršnog odbora Bundesbanke koji je pokušao da kaže šta sve u Nemačkoj ne funkcioniše i koji je pogodio osećanja velikog broja svojih zemljaka. Njegove dijagnoze su se u velikoj meri poklapale sa onim što su obično tvrdili konzervativci. Ipak, Saracin nije stvarao novu stranku, niti je želeo da napusti SPD.

Godinu dana pre nego što je objavljena Saracinova knjiga, konzervativni publicista Karlhajnc Vajsman (Karlheinz Weißmann) napisao je da se Nemačka nalazi $u$,šizofrenom položaju“. „Sa jedne strane konzervativno doživljava neočekivanu renesansu, postoje pokušaji sa sasvim različitih strana da se pojam ispuni novim sadržajem. Sa druge strane, konzervativcima nedostaje referentna tačka. ${ }^{\text {"84 }}$ Drugim rečima, Nemačka je bila država bez konzervativne stranke, što znači da je pre formiranja AfD nemački konzervativizam bio politički beskućnik i istovremeno svestan svog komplikovanog položaja. Formiranje AfD nije, dakle, bila slučajnost. Bio je to odraz duboke potrebe društva, kao i reakcija na upadljive posledice dugotrajne neograničene dominacije levice, odnosno pomeranja stranačkog spektra sve dublje ka levici. Drugim rečima, istorija nemačkog konzervativizma pokazuje da se nastanak i razvoj AfD ne mogu objasniti "procesom desolidarizacije u kontekstu neo-liberalne deregulacije“ ${ }^{85}$ kako to čine levičarski autori. Iako je evroskepticizam igrao ulogu inicijalne kapisle u formiranju AfD, nema sumnje da su razlozi za nastanak nove stranke mnogo dublji i da uključuju "temeljno nezadovoljstvo“ i razočaranje birača CDU/CSU i FDP koji su politiku Unije i liberala videli kao „premalo konzervativnu“, odnosno ",premalo liberalnu“, 86 ili čak kao stranke koje su ostale bez ikakvih ubeđenja, te su zbog toga spremne da vode bilo kakvu pa i tipično levičarsku - politiku koja u datom momentu obećava glasove. ${ }^{87}$

\footnotetext{
${ }^{84}$ Weißmann, Das konservative Minimum, S. 64.

${ }^{85}$ Häusler, Mut zur Wahrheit?, S. 9; Alexander Häusler, Die AfD: Eine rechtspopulistische Partei im Wandel, DGB Bundesvorstand, Berlin, 2016, S. 6.

${ }^{86}$ Simon Tobias Franzmann, „Die Wahlprogrammatik der AfD in vergleichender Perspektive" in: Mitteilungen des Instituts für Deutsches und Internationales Parteienrecht und Parteienforschung, Heinrich-Heine Universität, Düsseldorf, 2014, S. 115.

${ }^{87}$ Primera radi, CDU je iznenada i bez objašnjenja ukinula vojnu obavezu, iz korena promenila svoju energetsku politiku, suprotno prvobitnim obećanjima prihvatila politiku spasavanja evra, da bi najposle širom otvorila granice i legalizovala istopolne "brakove".
} 
Kada su brojni pokušaji da se ti trendovi zaustave akcijom iz same stranke ${ }^{88}$ i da se promeni kurs doživeli neuspeh, nije više bilo izbora i formirana je nova partija. Uostalom, to su eksplicitno izrekli i osnivači stranke Bernd Luke (Bernd Lucke), ${ }^{89}$ Konrad Adam (Konrad Adam) ${ }^{90}$ i Gauland ${ }^{91}$ koji su jasno pokazali tačke na kojima je CDU odstupila od svojih izvornih pozicija, odnosno „presekla svoje konzervativne korene“. Adam podvlači, da je u CDU od tri korena (socijalnog, liberalnog i konzervativnog) treći zanemaren i smanjen do beznačajnosti.

Istorija nemačkog konzervativizma posle Drugog svetskog rata ne može se opisati kao uspešna. To nije bila samo posledica opštih trendova, koji su doveli do pada konzervativnih pozicija u Evropi i Severnoj Americi, već i posledica specifičnih, nemačkih uslova, nemačke povesti i nemačke politike. Nemačka desnica nije imala ni svog Regana ili Tačerovu (Margaret Thatcher), niti pre toga svog Goldvotera (Barry Goldwater). Čak nije imala ni časopis koji bi se mogao uporediti sa onim što je u Americi značio National Review. Sve vreme nakon rata konzervativizam $u$ Nemačkoj je bio $u$ defanzivi i u povlačenju pred levicom, te je postepeno gubio uporišta, računajući tu i jedinu stranku koja je bila otvorena za konzervativce. Svi pokušaji da se desnica konsoliduje ostali su dugoročno bezuspešni, a neuspeh Republikanaca da se konstituišu kao respektabilna desna stranka ostavio je snažne posledice na nemačke konzervativce. Tokom posleratnog perioda, konzervativizam se i sam menjao i odustajao od svojih starih zahteva, što se jasno vidi kada se uporede zahtevi koji su se mogli artikulisati pedesetih ili šezdesetih sa onim što se traži posle 2000. godine. Do koje mere su sužene granice onoga što desnica može da zastupa vidi se po tome što se danas kao na opasan radikalizam gleda na ono što je još devedesetih predstavljalo

${ }^{88}$ Pored pokušaja pobune protiv Kola iz 1980, treba reći da su u okviru CDU delovale različite inicijative koje su išle za tim da stranku vrate ka hrišćansko-konzervativnim korenima, ili barem da zaustave pomeranje ka levici (Christlich-Konservatives Deutschland-Forum, Arbeitskreis Konservativer Christen, Aktion Links-trend stoppen).

${ }^{89}$ Bernd Lucke, „Euro-Retter auf der falschen Spur“ Frankfurter Allgemeine Zeitung, 11. 6. 2011. http://www.faz.net/aktuell/wirtschaft/eurokrise/wirtschaftsordnungeuro-retter-auf-der-falschen-spur-1494362-p5.html 25/4/2020.

${ }^{90}$ Konrad Adam, „Muttis Ödnis“, Junge Freiheit, 31. 8. 2012, http:/ / www.jf-archiv.de/ archiv12/201236083151.htm 25/4/2020.

${ }^{91}$ Gauland, Anleitung zum Konservativsein, S. 135. 
sasvim legitimne zahteve. Od stava "mi nismo useljenička zemlja" relativno brzo se došlo do "mi nismo klasična useljenička zemlja“. ${ }^{92} \mathrm{U}$ takvim uslovima teško da se može govoriti o bilo kakvom usponu desnice i, u najboljem slučaju, može se razmišljati o zaustavljanju pada ili o reakciji koja se nužno pojavljuje nakon kulturne vladavine levice. Pre je po sredi dobrodošla dopuna sistemu koji je već dugo funkcionisao bez desnog pola. Nervozne reakcije sa levice, koje u svakoj inicijativi sa desne strane vide opasnost i razlog za mobilizaciju, možda više govore o suženom razumevanju demokratije onih koji slobodu vide kao privilegiju za svoje istomišljenike, nego o stvarnoj radikalizaciji na desnici.

\section{Alternativa za Nemačku}

Kada se govori o rastu desnice $u$ Nemačkoj ima se u vidu uspeh AfD. Već od osnivanja vode se polemike o tome kakva je to zapravo stranka. Članovi i simpatizeri ${ }^{93}$ su je videli kao umerenu, evroskeptičnu, liberalnokonzervativnu stranku, što uostalom stoji i u preambuli stranačkog programa. ${ }^{94}$ Gauland, kao jedan od visokih funkcionera AfD, uvek je naglašavao svoju pripadnost berkovskoj tradiciji konzervativizma, pri čemu u svojoj kritici nije štedeo nemačku konzervativnu tradiciju uključujući i predstavnike konzervativne revolucije. ${ }^{95}$ Čak je i Bjern Heke (Björn Höcke), koji važi za predstavnika desne struje u stranci, jasno naglasio da je AfD liberalno-konzervativna i patriotska stranka. ${ }^{96}$ Između liberalnih i konzervativnih elemenata nema napetosti, jer kako je u jednom intervjuu rekao funkcioner stranke Mark Jongen (Marc Jongen) „istinski liberal danas

${ }^{92}$ Gauland, Anleitung zum Konservativsein, S. 55. Pogledati takođe i intervju koji je bivši socijal-demokratski kancelar, Helmut Smit, dao za Frankfurter Rundschau od 12. 9. 1992, gde kaže da predstavu da jedno moderno društvo mora biti u položaju da se etablira kao multikulturalno sa što je moguće većim brojem kulturnih grupa, drži za sumanutu.

${ }^{93}$ Nicole Berbuir, Marcel Lewandowsky, and Jasmin Siri, "The AfD and its Sympathisers: Finally a Right-Wing Populist Movement in Germany?" in: German Politics, 24:2, Routledge, London, 2015, p. 169.

94 „Programm für Deutschland, Das Grundsatzprogramm der Alternative für Deutschland“, Alternative für Deutschland, Berlin, 2016, S. 6.

${ }^{95}$ Gauland, Anleitung zum Konservativsein.

${ }^{96}$ Björn Höcke, „Die AfD hat das Potential zu einer neuen Volkspartei“ in: Neue Ordnung, 4/15, Graz, 2015, S. 18. 
je konzervativan, pa čak i ponekad reakcionaran" ${ }^{97} \mathrm{U}$ istom intervjuu, Jongen AfD opisuje kao tradicionalnu stranku srednje klase, koja se zalaže za vladavinu prava, vernost principima ustava i tržišnoj ekonomiji. Najvažniji predstavnici stranke dolaze iz liberalno-konzervativnog miljea, dok simpatizeri dolaze iz svih političkih tabora ${ }^{98}$, uključujući i članove sindikata. Imajući to u vidu, Gauland o svojoj stranci govori kao o pokretu u kome su okupljene dve stranke: stranka srednjeg sloja i ekonomski gledano srednjeg staleža koji je "kičma zemlje“ i stranke običnih ljudi, „čiji su poslovi mizerno plaćeni ili više uopšte ne postoje“.${ }^{99} \mathrm{~Pa}$ ipak, jedan broj istraživača je stranku označio kao "populističku“, odnosno desnopopulističku ${ }^{100}$ i most između ekstremne desnice i klasičnog konzervativizma, mešavinu, desnog populizma i nacionalno-liberalnih karakteristika. ${ }^{101}$ Istraživači koji dolaze sa levice posebno naglašavaju veze između AfD i „,nove desnice“, ${ }^{\prime 02}$ iako nije uvek baš sasvim jasno šta se pod tim pojmom tačno podrazumeva. O kakvoj je stranci reč i da li njeni izborni uspesi mogu biti razlog za zabrinutost?

AfD je nastala 2013. godine, i uskoro je postalo jasno da je reč o stranci koja je više od grupe kritičara evra. Ideja je bila da se ujedine različite konzervativno-liberalne struje i formira „istinska alternativa“. Veliki broj osnivača bili su bivši funkcioneri ili članovi CDU (Luke, Adam, Gauland, a i Heke je kao mladić bio član omladine CDU), dok su ostali došli iz krugova bliskih liberalnoj FDP (Hans-Olaf Henkel). Stranka je zamišljena kao spoj liberalne ekonomije, nacionalnih liberala i nacionalnih konzervativaca. Od samog početka stranka je uspostavila jasnu distancu prema ekstremnoj desnici, tako da je bivšim članovima ekstremno desnih grupa zabranjeno učlanjivanje.

${ }^{97}$ Marc Jongen, „Das Märchen vom Gespenst der AfD“, Cicero, 22. 1. 2014. http:/ / cicero.de/berliner-republik/afd-ein-manifest-fuer-eine-alternative-fuer-europa/ $5689425 / 4 / 2020$.

${ }^{98}$ Marcel Lewandowsky, Alternative für Deutschland (AfD), a New Actor in the German Party System, Friedrich-Ebert-Stiftung, Berlin, 2014, S. 2, 6.

${ }^{99}$ Alexander Gauland, „Populismus und Demokratie“, Sezession, Heft, 88, Schnellroda, 2019, S. 18.

${ }^{100}$ Häusler, Mut zur Wahrheit?; Häusler, Die AfD: Eine rechtspopulistische Partei im Wandel, S. 4 .

${ }^{101}$ Franzmann, „Die Wahlprogrammatik der AfD in vergleichender Perspektive“, 123.

${ }^{102}$ Häusler, Die AfD: Eine rechtspopulistische Partei im Wandel, S. 26. 
Osnovna pitanja na koja se stranka fokusira su: evro i evropska politika, unutrašnja bezbednost, porodica i porodične vrednosti, imigracija, islamizacija i politički islam te energetska politika. Ukratko, skoro sva ova pitanja mogu se svesti na pitanja identiteta ${ }^{103}$ i suvereniteta.

Po pitanju evropske politike AfD smatra da je evro čisto politički projekat što ga čini nestabilnim, a paket spašavanja evra katastrofalnim. Zapravo, smatra se da je evro propali, ,politički projekat" , ${ }^{104}$ da je štetan za Nemačku, ali i za ostale zemlje poput Grčke i EU u celini, i da vodi ka „,svađi među nacijama“ ${ }^{105}$ Slično Saracinu, AfD predlaže vraćanje nemačke nacionalne valute i "uređeno ukidanje“ eksperimenta sa evrom. ${ }^{106}$ Ipak, stranka nije protiv EU kao celine pa podržavaju zajedničko tržište, ali se protive centralizaciji, kao i velikoj i agresivnoj briselskoj administraciji, odnosno stvaranju ogromne, evropske federalne države $u$ čemu vide opasnost za nacionalni suverenitet, kao i za demokratiju ${ }^{107}$, vladavinu prava i tržišnu privredu. U tom smislu, AfD kritikuje EU sa demokratskih pozicija. Pojedini (bivši) funkcioneri su u svojim tekstovima pravili paralele između današnje EU i nekadašnjeg SSSR-a. ${ }^{108}$ Umesto centralizovane evropske super-države odnosno „sjedinjenih država Evrope“, AfD zahteva više slobode i takmičenja među evropskim državama ili Evropu otadžbina. ${ }^{109}$ To podrazumeva povratak EU na nivo ekonomske unije, zasnovane na interesima članica, odnosno suverenih i labavo povezanih država.

U spoljnoj politici AfD ne vidi Rusiju kao pretnju, i po pitanju odnosa prema Rusiji i prema NATO-u AfD nastoji da vodi izbalansiranu politiku izbegavajući radikalizaciju. ${ }^{110}$

Pitanje nekontrolisane imigracije, posebno iz islamskih zemalja, jedno je od najvažnijih za ovu stranku, ali i pitanje zbog koga je stranka najčešce

\footnotetext{
103 „Centralna politička tema budućnosti glasi: identitet. To se ne misli u smislu etničke čistote koja nikada nije postojala." Gauland, „Populismus und Demokratie“, S. 20.

104 „Programm für Deutschland“, S. 18.

105 Ibid., S. 20.

${ }^{106}$ Ibid., S. 18.

${ }^{107}$ Ibid., S. 17.

${ }^{108}$ Henkel, „Der deutsche Migrations-Skandal“.

109 „Programm für Deutschland“, S. 16.

${ }^{110}$ Ibid., S. 30-31. Za odnos prema Rusiji vidi: Gauland, Anleitung zum Konservativsein, S. 102-107.
} 
na udaru. Ono je bilo važno i pre migrantske krize, ali je posle 2015. postalo najznačajnije i blisko povezano sa pitanjem identiteta, odnosno pitanjem opstanka pravne države. AfD zastupa stav da Nemačka nije klasična useljenička zemlja. Ipak, AfD ne želi da sasvim zaustavi imigraciju, već ukazuje na primere kanadskog ili australijskog modela. ${ }^{111}$ Takođe, insistira se na razlici između političkih izbeglica i ljudi koji beže od rata, s jedne, i neregularne, ilegalne imigracije s druge strane. Po ovom pitanju AfD vodi tipičnu kulturno-konzervativnu politiku koja polazi od uvida da sopstveno ima prednost nad stranim, te da imigracija ima ne samo ekonomske već i kulturne granice. Takođe, $\mathrm{u}$ stranačkom programu stoji da islam ne pripada Nemačkoj, a povećanje broja muslimana u zemlji vidi se kao opasnost za zemlju, društvo i vrednosti. ${ }^{12}$ Naglasak je na tome, da je islam, koji se ne pridržava pravila ili je u konfliktu sa pravnim poretkom, i koji sebe smatra jedinom pravom verom, $u$ sukobu sa nemačkim pravim poretkom i kulturom. Ipak, AfD prihvata da postoje građani Nemačke koji su muslimani i da su mnogi od njih "odani zakonu i dobro integrisani $u$ društvo", te stoga vredni i prihvaćeni članovi društva. ${ }^{113}$ Reč je o umerenom, liberalno-konzervativnom pristupu ovom pitanju, ali i o odlučnoj kritici multikulturalističke ideologije i političkog islama. Dakle, Nemačka treba da bude otvorena za integrisane muslimane, ali islam treba da ostane van javne sfere, što znači da nema mesta za burke i minarete, kao ni za paralelna društva u kojima vlada šerijatsko pravo. To takođe isključuje da protivustavne snage mogu voditi džamije ili da one budu finansirane stranim novcem, a od imama se traži da govore nemački jezik. ${ }^{114}$ Multikulturalizam se smatra propalim ${ }^{115}$ i shvata se kao „ozbiljna pretnja socijalnom miru i opstanku nacije kao kulturnog jedinstva " ${ }^{116}$ odnosno kao put da se društvo razjedini i pocepa na paralelna društva. Umesto toga, od useljenika se zahteva integracija $u$ dominantnu kulturu. Ta dominantna

\footnotetext{
111 „Programm für Deutschland“, S. 58.

112 Ibid., S. 49.

${ }^{113}$ Ibid.,S. 49.

114 Ibid., S. 49-50.

115 „Multikulturalno društvo je propalo.“ Ibid., p. 63. Svojevremeno je i Angela Merkel dala sličnu izjavu, ali se ostalo na tome i iz tog uvida nisu izvedene nikakve posledice. Naprotiv, nekoliko godina kasnije došla je sasvim suprotna izjava da islam pripada Nemačkoj. Na to je reagovao Bernd Luke tvrdnjom da je islam stran Nemačkoj. ${ }^{116}$ Ibid., S. 47.
} 
kultura počiva na tri izvora: religijskoj tradiciji hrišćanstva; naučnohumanističkoj tradiciji čiji su antički koreni obnovljeni u renesansi i prosvetiteljstvu; te rimskom pravu na kome počiva pravna država. ${ }^{117}$

Važna tačka u programu AfD su i porodica i porodična politika. ${ }^{118}$ Ovde se takođe pokazuje konzervativno usmerenje AfD, jer je naglasak na zaštiti tradicionalnih porodičnih vrednosti. Smatra se da je jedino dugoročno rešenje za negativne demografske trendove $u$ Nemačkoj veća stopa rađanja kod domaćeg stanovništva, što se može postići stimulativnom porodičnom politikom. Stoga se zahteva da se prestane sa "diskriminacijom majki sa punim radnim vremenom ", ${ }^{119}$ kao i okončanje "finansijskog zanemarivanja porodica“ ${ }^{120} \mathrm{U}$ tu svrhu AfD predlaže i uvođenje beskamatnih zajmova za porodice koje žele da poseduju sopstvene stanove, kao i posebnu državnu pomoć za višečlane porodice. Stranka se protivi tome da se abortus proglasi za ljudsko pravo.

U ekonomiji AfD se zalaže za socijalno-tržišnu privredu u skladu sa nemačkim modelom iz pedesetih godina i protivi se potiskivanju tržišne privrede odnosno onome što Jongen naziva "bankovni socijalizam“. U tom smislu, stranka se izričito poziva na konzervativno-liberalne ekonomiste poput Valtera Ojkena (Walter Eucken), Vilhelma Repkea (Wilhelm Röpke) i Alfreda Miler-Armaka (Alfred Müller-Armack). ${ }^{121}$ Veruje se da su privatno vlasništvo i tržišna ekonomija ugroženi od strane EU i njene "nove dirigovane ekonomije“. Prema Jongenu, AfD je protiv proletarizacije srednje klase, kao i protiv do sada neviđene eksproprijacije poreskih obveznika koja je rezultat "strukturne korupcije“ u politici. ${ }^{122}$

Smatrajući da su demokratija, vladavina prava i tradicionalne vrednosti ugrožene od strane otuđenih i neodgovornih političkih i medijskih elita, AfD se zalaže za uvođenje direktne demokratije u skladu sa švajcarskim modelom. ${ }^{123} \mathrm{U}$ tom smislu, stranka se zalaže za izjašnjavanje građana o

\footnotetext{
117 Ibid., S. 47.

${ }^{118}$ Ibid., S. 40-41. U jednom intervjuu Heke kaže da AfD u budućnosti vidi kao porodičnu stranku i da traži "odlučujući obrt u porodičnoj politici“. Höcke, "Die AfD hat das Potential zu einer neuen Volkspartei“", S. 19.

119 „Programm für Deutschland“, S. 43.

${ }^{120}$ Ibid., S. 37.

${ }^{121}$ Ibid., S. 67.

122 Jongen, „Das Märchen vom Gespenst der AfD“.

123 „Programm für Deutschland“, S. 9.
} 
evropskoj valuti. Direktna demokratija shvata se i kao instrument za ograničavanje uticaja političkih partija i političke klase budući da se polazi od uverenja da svemoć političkih stranaka i njihova eksploatacija države ugrožava demokratiju. ${ }^{124} \mathrm{U}$ tom smislu, AfD traži direktan izbor predsednika.

AfD sebe smatra patriotskom strankom, pa čak i jedinom patriotskom strankom u Nemačkoj. ${ }^{125} \mathrm{U}$ programu se kaže da su nacija i nacionalna država jedini mogući okvir za uspešno funkcionisanje demokratije i vladavinu prava. ${ }^{126}$ Sa druge strane, podvlači se da stranka nije nacionalistička, a sadašnje nemačke granice se ne dovode $u$ pitanje. Jongen izričito odbacuje ideju da Nemačka ima misiju da bilo kome nameće svoje vrednosti. ${ }^{127}$ Ovo razlikovanje između nacionalizma kao ratoborne ideologije i nacionalne svesti i nacionalne privrženosti kao normalnih i zdravih osećanja i osećaja pripadnosti, takođe je klasično konzervativno mesto. ${ }^{128}$ Tako AfD insistira na očuvanju nemačkog kulturnog nasleđa, jezika i tradicije za buduće generacije. ${ }^{129}$ Upravo se tu vidi da patriotizam AfD nije ni ofanzivan, ni ratoboran, već defanzivan i otvoren prema drugim nacijama ili kako u sažetoj formi kaže Gauland: „Osećaj za zavičaj i osećaj za svet se međusobno uslovljavaju. “130

Poređenjem AfD sa istorijskim izrazima nemačkog posleratnog konzervativizma, vidi se da je reč o stranci koja ne samo što je verna demokratiji i ne teži uspostavljanju nekog autoritarnog sistema, nego se povrh toga zalaže za uvođenje instrumenata direktne demokratije. ${ }^{131}$ AfD

${ }^{124}$ Ibid., S. 11. „Mi ne smatramo sebe pametnijim od naroda. Mi nemamo strah od naroda." Gauland, „Populismus und Demokratie“, S. 20.

${ }^{125}$ U jednom intervjuu Gauland kaže da sve ostale stranke u Nemačkoj žele da se evropska zajednica (pre ili kasnije) pretvori u evropsku federaciju, dok se jedino AfD zalaže za očuvanje nacionalne države, te da je to temeljna tačka neslaganja. Alexander Gauland, „Wir wollen den deutschen Nationalstaat erhalten!" , Freilich, No. 2, 2019, S. 13.

126 „Programm für Deutschland“, S. 17.

${ }^{127}$ Jongen, „Das Märchen vom Gespenst der AfD“.

${ }^{128}$ Roger Scruton, How to be a Conservative, Bloomsbury, London, 2014, pp. 31-40. Još jedno izričito distanciranje od nacionalizma može se pronaći u knjizi Aleksandera Gaulanda, osnivača AfD. Vidi: Gauland, Anleitung zum Konservativsein.

129 „Programm für Deutschland“, S. 47.

${ }^{130}$ Gauland, Anleitung zum Konservativsein, S. 10-11.

131 „Demokratski pokret i konzervativna društvena snaga se ne isključuju. To su dva različita puta kojima se može doći do cilja demokratski legitimizovanih promena." Ibid., S. 138. 
se ne orijentiše na borbu protiv „prosvetiteljskog sekularizma“ kao što je to bio slučaj sa katoličkim konzervativizmom iz pedesetih godina, niti deli njihov antimodernizam. Štaviše, stranka pored hrišćanstva izričito navodi "naučno-humanističku tradiciju" kao jedan od tri izvora nemačke dominantne kulture. $\mathrm{Za}$ razliku od CDU iz pedesetih godina ili Republikanaca, AfD ne dovodi u pitanje sadašnje granice i ne zahteva povratak izgubljenih teritorija. ${ }^{132}$ Svakako, AfD je više zabrinut za aktuelna pitanja koja ranije nisu postavljana, kao što su evro, evropska politika, imigracija, multikulturalizam, politički islam, porodica. Čak ni po pitanju imigracije AfD ne odbacuje načelno svaku imigraciju, već se zalaže za regulisano useljavanje. Ni u kritici multikulturalizma AfD ne odstupa od standardne konzervativno-liberalne kritike. Sa druge strane, AfD je zadržala neke tačke iz tradicije nemačkog posleratnog konzervativizma, a pre svega naglasak na socijalno-tržišnu privredu.

\section{Desnica izvan AfD}

Ako je AfD daleko od opasne stranke, logično se postavlja pitanje da li se izvor opasnosti može tražiti na drugim mestima. Iako u Nemačkoj postoji "mozaik desnica“133 (Benedikt Kajzer), koja se sastoji od većeg broja časopisa, internet portala, studentskih udruženja, omladinskih grupa, izdavačkih kuća, lokalnih inicijativa, intelektualnih krugova i pojedinaca, u ovom trenutku desnica van AfD, kao respektabilna politička snaga ne postoji. Veliki delovi „mozaik desnice“ sarađuju sa AfD ili prećutno podržavaju ovu stranku. Desni krugovi, koliko god bili heterogeni, u većini ne vide sebe kao konkurenciju AfD i nema prostora za stvaranje nove stranke.

Sa druge strane, pokušaj bivših članova AfD okupljenih oko Lukea da formiraju svoju stranku (Liberalno-konzervativni reformisti) pokazao se neuspešnim. Takođe i preostala liberalno-konzervativna struja unutar CDU, okupljena u okviru WerteUnion, je u sopstvenoj stranci marginalizovana i bez izgleda da se nametne kao značajna snaga. To znači da ni u prostoru između CDU i AfD nema izgleda za stvaranje konkurencije AfD.

${ }^{132}$ Gauland u svojoj knjizi pita „Nismo li Šleziju drugačije izgubili nego što smo je dobili?" Ibid., S. 25.

${ }^{133}$ Za pregled "mozaik desnice“ u Nemačkoj vidi: Arndt Novak, Jonas Schick, "Deutschland von reschts", Freilich, No. 2, 2019, S. 22-35. 
Radikalna desnica takođe nema kapaciteta za značajnije političko delovanje. NPD nikada u svojoj istoriji nije uspela da uđe u Bundestag, iako je 1969. sa 4,3\% osvojenih glasova bila blizu tog cilja. Međutim, nakon tog izbornog neuspeha dolazi do rascepa $u$ stranci, a zatim do dalje radikalizacije i preživljavanja na dubokoj margini. NPD je mogla računati tek na relativne uspehe na pokrajinskim izborima. Poslednjih godina ova stranka je izgubila i onu podršku koju je imala u pojedinim pokrajnama, pa tako i mesta u pokrajinskim skupštinama. Pored toga, NPD i druge slične grupe se stalno nalaze pred opasnošću da budu zabranjene kao protivustavne organizacije. Time je taj deo desnog korpusa sveden na marginalne lokalne grupe bez ikakvog političkog značaja.

Medijima su do sada najzanimljiviji bili podaci vezani za napade i krivična dela iza kojih stoje neonacisti. Premda je i u Nemačkoj bilo slučajeva desnog terorizma, od kojih je najpoznatiji ubistvo političara Valtera Libkea (Walter Lübke) iz 2019. godine, do sada se pokazalo da su u pitanju bili pojedinačni slučajevi bez ikakve organizacije u pozadini. Jedina značajnija desna teroristička grupa bila je tročlana NSU (Nationalsozialistischer Untergrund). Iako medijski atraktivno, desničarsko nasilje daleko je od toga da postane ikakva pretnja, pogotovo ako se uporedi sa organizovanim akcijama islamista. Primera radi, 2006. godine se tvrdilo da su neonacisti počinili 12.238 krivičnih dela. Iako bi čitalac na osnovu takve brojke mogao zaključiti da je reč o pravoj poplavi i da SA jedinice ponovo zauzimaju ulice, reč je o nečem sasvim drugom. Kako kaže Henkel, ovaj broj dela je visok samo zato što je prag za ono što će važiti kao "ekstremno desno krivično delo“ izuzetno nizak. Naime, u gornju cifru ulazi 8.738 „delikata propagande“ što podrazumeva dela kao što su prikazivanje zabranjenih simbola, slušanje zabranjene muzike, zauzimanje zabranjenih stavova vezanih za prošlost i slične stvari koje bi retko ko okarakterisao kao posebno opasne. Broj ozbiljnih telesnih povreda koje se stavljaju na račun neo-nacistima je, prema Henkelu, 726, od čega najveći deo otpada na sukobe sa jednako nasilnim ekstremnim levičarima sa tzv. antifašističke scene. ${ }^{134}$ Henkel se takođe poziva i na izjavu ondašnjeg ministra unutrašnjih poslova, Volfganga Šojblea (Wolfgang Schäuble), iz maja 2007. u kojoj je ovaj predstavljajući izveštaj Službe za zaštitu ustava konstatovao, da je veći broj napada koje je počinila ekstremna levica nego

${ }^{134}$ Henkel, „Der deutsche Migrations-Skandal“. 
ekstremna desnica. ${ }^{135}$ Treba imati u vidu da su ove statistike nastale pre 2015. godine i talasa useljavanja milion ljudi koji je doveo do opšteg porasta nasilja. Tako i izveštaj iz 2018, uz povećanje broja krivičnih dela, pokazuje sličnu strukturu onome iz 2006, i ponovo više od polovine krivičnih dela ekstremne desnice otpada na "delikte propagande“ ${ }^{136}$

\section{Evropska saradnja}

Priča o ,jačanju desnice“ ne bi bila celovita ukoliko se u obzir ne uzme i saradnja na evropskom nivou. Naime, kada se govori o jačanju desnice, često se naglašava međusobna povezanost desnih stranaka, odakle se ponovo izvode razlozi za zabrinutost, ${ }^{137}$ iako nije uvek najjasnije šta se sve podrazumeva pod pojmom saradnje, kao ni to zbog čega bi uspostavljanje veza između stranka i grupa desne orijentacije samo po sebi moglo biti shvaćeno kao bezbednosna pretnja.

Na osnovu nemačkog primera vidi se da je desnica na evropskom nivou relativno slabo povezana, ili barem slabije nego što je to slučaj sa levicom. To je, s jedne strane, uslovljeno već različitom istorijom, kao i različitom snagom desnih stranaka u Evropi. Primera radi, AfD je još uvek mlada stranka, a njeno članstvo i biračko telo još uvek je relativno malobrojno, što je čini slabijom od njoj ideološki bliske austrijske FPO.

${ }^{135}$ Pri tome treba imati na umu da je AfD kao stranka od samog osnivanja na meti nasilnika sa levice. Poznati su slučajevi napada na štandove i prostorije stranke, ali i na kuće i stanove funkcionera, računajući tu i paljenje automobila. Nisu retki ni fizički napadi na članove i funkcionere stranke, a verovatno najteži slučaj dogodio se 2019. godine kada je pretučen poslanik Frank Magnic (Frank Magnitz), koji je od posledica napada završio u bolnici.

136 „Verfassungsschutzbericht 2018“, Bundesministerium des Innern, für Bau und Heimat, Berlin, 2019, S. 24. Ovde treba imati na umu da je broj dela koje vrši levica nužno manji, budući da simboli isticanje simbola levog ekstremizma nije kažnjivo.

${ }^{137}$ Videti na primer pristrasan i površan članak Nenada Radičevića u kome se čak ide dotle da se pominje stvaranje ",desničarske profašističke internacionale" koja nastaje „u samom srcu Zapada“: Nenad Radicevic, „Mi smo njihov glas': Nemačka ekstremna desnica stvara savezništva na Balkanu", https:/ / balkaninsight.com/ 2019/10/24/mi-smo-njihov-glas-nemacka-ekstremna-desnica-stvara-saveznistvana-balkanu/?lang=sr 5/8/2020. Zanimljivo je da je članak je nastao u okviru projekta Resonant Voices Initiative koji je finansiran od strane fonda za unutrašnju bezbednost Evropske unije, čime se jasno sugeriše da se svaki oblik saradnje na desnici sagledava $u$ kontekstu unutrašnjeg bezbednosnog izazova. 
Sa druge strane, postoje i programske prepreke povezivanju desnice $\mathrm{u}$ Evropi koje otežavaju zajedničko nastupanje. Naime, pored velikog broja nesumnjivih programskih sličnosti, desne i konzervativne stranke $u$ Evropi pokazuju i brojne razlike koje utiču na mogućnosti uspostavljanja saradnje. Ta distanca se jasno opaža u okviru Evropskog parlamenta gde su desne stranke organizovane $\mathrm{u}$ nekoliko različitih poslaničkih grupa, pa čak i u okviru iste grupe ne vlada nužno konsenzus po svakom pitanju. Da između evropskih desnih stranaka koje su uspostavile saradnju postoje zajedničke tačke, ali i različiti „,nacionalni ciljevi“, izbore 2019, kada je zapazio da ti ciljevi „nisu uvek kompatibilni sa predstavama" njegove stranke i kao primer uzeo italijansku Ligu, čiju finansijsku politiku je nazvao "pogrešnom", dok je migrantsku politiku označio kao „,ispravnu“ ${ }^{\prime 38}$ Međutim, nije reč samo o razlikama koje bi se ticale finansijske politike, nego i o dubljim rezervama, pa tako Gauland kod Marin Le Pen prepoznaje "antinemački resantiman“ za koji kaže "da se ne sme prevideti“. ${ }^{139}$ To znači da čak i kada su desne stranke na evropskom nivou upućene jedne na druge i na međusobno povezivanje, do saradnje dolazi uz oprez i uz uvažavanje kulturnih i istorijskih specifičnosti. U meri u kojoj se interesi pojedinačnih evropskih zemalja mogu međusobno razlikovati, $u$ istoj meri će i razlike između desnih stranaka više dolaziti do izražaja. Drugačije rečeno, na desnici nema nikakve zacrtane idealne slike Evrope, ka kojoj treba težiti i na čijem ostvarenju se mora raditi zajedničkim snagama, niti koncepata koji bi se nametali drugima. Štaviše, u najvećem broju slučajeva, konzervativci upravo apeluju na odbranu od onoga što smatraju nametanjem univerzalnih, gotovih rešenja ili uniformisanjem. Samim tim, ne postoji ni nekakav „glavni štab" niti "centralni komitet" evropskih desničara ili konzervativne internacionale, koji bi formulisao ciljeve, koordinirao aktivnosti pojedinačnih partija i posredovao u sporovima. Prema tome, ni sa te strane ne može govoriti o nekakvoj desničarskoj pretnji.

Slično se može reći i za saradnju radikalnih odnosno nasilnih grupa. Ni tu nema izražene prekogranične saradnje, pogotovo ne onakve kakva je karakteristična za, na primer, islamski terorizam. Primera radi, aktivnosti NSU bile su ograničene na Nemačku i nema podataka o značajnijim aktivnostima nekakve međunarodne desne terorističke mreže.

${ }^{138}$ Gauland, „'Wir wollen den deutschen Nationalstaat erhalten!", S. 13.

139 Ibid. 


\section{Zaključak}

Na nemačkom primeru postaje jasno da popularna predstava o rastu desnice i o opasnosti koju bi to jačanje predstavljalo ne odgovara stvarnosti. Ukoliko se stvar sagleda $u$ istorijskoj perspektivi vidi se da se desnica i generalno konzervativizam u Nemačkoj od kraja Drugog svetskog rata nalazi u defanzivi, odnosno da se od šezdesetih godina intelektualna i medijska scena toliko pomerila ulevo da se može govoriti o levoj kulturnoj hegemoniji koja nije dovedena u pitanje ni nakon pada komunizma. Desnica ne samo da je gubila pozicije $u$ institucijama, nego je vremenom i sama sve više popuštala zahtevima vremena. Stranke za koje su nekada konzervativci glasali su se snažnije pomerale ulevo ostavljajući svoje bivše birače bez političke domovine. Sasvim je logično da je taj proces morao izazvati nastanak nove, desne, konzervativne političke stranke, što se i dogodilo formiranjem AfD. Pri tome, AfD je prema svom programu, kao i izjavama svojih vodećih funkcionera, stvorena kao liberalno-konzervativna stranka bez primesa desnog radikalizma. Iako je desni ekstremizam svakako prisutan u društvu, reč je o marginalnim i politički potpuno beznačajnim grupama koje teško da mogu predstavljati ozbiljnu opasnost, pogotovo kada se uporede sa drugim bezbednosnim izazovima. Istovremeno, na evropskom i svetskom nivou stvari su daleko od homogenog, desnog pokreta, niti je na vidiku nekakva desna internacionala. Sve to navodi na zaključak da se ne može govoriti o nekakvom potencijalno opasnom jačanju desnice u Nemačkoj, nego je pre reč je o ideološkoj formuli sračunatoj na diskreditaciju protivnika i mobilizaciju svih protiv "desne opasnosti“. Štaviše, konsolidovanje desnice i diverzifikacija političke ponude predstavljaju dobrodošlu dopunu i mogu uticati na konkurenciju ideja i programa, te tako pozitivno delovati na politički život u celini. Uostalom, demokratija živi od sukoba mišljenja i argumentovanih debata, a propada u zagušljivoj atmosferi bezalternativnosti, nametnute političke korektnosti i svetonazornog konsenzusa u kojoj se sa neistomišljenicima ne razgovara.

\section{Bibliografija}

Bakić, Jovo, Evropska krajnja desnica, (1945-2018), Clio, Beograd, 2019.

Benoa, Alen de, Komunizam i nacizam: 25 ogleda o totalitarizmu u XX veku (1917-1989), Centar za izučavanje tradicije „Ukronija“, Beograd, 2007. 
Berbuir, Nicole, Lewandowsky, Marcel, Siri, Jasmin, "The AfD and its Sympathisers: Finally a Right-Wing Populist Movement in Germany?" in: German Politics, 24:2, Routledge, London, 2015, pp. 154-178.

Berlin, Jörg, Joachim, Dierk, Keller, Bernhard, Ulrich, Volker, „NNeofašizam u Saveznoj Republici Nemačkoj" u: Marksizam u svetu, br. 4-5, Beograd, 1983, str. 243-274.

Bergsträsser, Ludwig, Geschichte der politischen Parteien in Deutschland, Isar Verlag, München 1952.

Beyme, Klaus von, Konservatismus: Theorien des Konservatismus und Rechtsextremismus im Zeitalter der Ideologien 1789-1945, Springer Fachmedien Wiesbaden 2013.

Clemenz, Manfred, „Prilog fenomenologiji fašizma“ u: Fašizam i neofašizam, Fakultet političkih nauka i Centar društvenih djelatnosti SSOH, Zagreb, 1976, str. 20-27.

Franzmann, Simon Tobias, „Die Wahlprogrammatik der AfD in vergleichender Perspektive" in: Mitteilungen des Instituts für Deutsches und Internationales Parteienrecht und Parteienforschung, Heinrich-Heine Universität, Düsseldorf, 2014, S. 115-125.

Gauland, Alexander, „Populismus und Demokratie“, Sezession, Heft, 88, Schnellroda, 2019, S. 14-20.

Gauland, Alexander, „Wir wollen den deutschen Nationalstaat erhalten!", Freilich, No. 2, 2019, S. 10-20.

Gauland, Alexander, Anleitung zum Konservativsein. Zur geschichte eines Wortes, Landt Verlag, Berlin, 2017.

Geißler, Heiner, Der Irrweg des Nationalismus, Beltz Athenäum,Weinhem, 1995.

Gerd-Klaus Kaltenbrunner, Der schwierige Konservatismus. Definitionen, Theorien, Porträts, Nicolaische Verlagsbuchhandlung, Herford, Berlin, 1975.

Habermas, Jürgen, „Kritika kulture kod neokonzervativaca u SAD i SR Njemačkoj" u: Marksizam u svetu, broj 4-5, Beograd, 1983, str. 21-38.

Häusler, Alexander, Die AfD: Eine rechtspopulistische Partei im Wandel, DGB Bundesvorstand, Berlin. 
Häusler, Alexander, Mut zur Wahrheit? Entstehungskontext, Entwicklung und gesellschaftspolitische Positionen der "Alternative für Deutschland", FORENA, Düsseldorf, 2014.

Höcke, Björn, „Die AfD hat das Potential zu einer neuen Volkspartei“ in: Neue Ordnung, 4/15, Graz, 2015, S. 16-19.

Kailitz, Steffen, Politischer Extremismus in der Bundesrepublik Deutschland. Eine Einführung, VS Verlag für Sozialwissenschaften, Wiesbaden, 2004.

Kisić, Izabela (ur.) Desni ekstremizam u Srbiji, Helsinški odbor za ljudska prava u Srbiji, Beograd, 2020.

Kondylis, Panajotis, „Die deutsche 'Sonderweg' und die deutschen Perspektiven" in: Kondylis, Panajotis, Das Politische im 20. Jahrhundert: Von den Utopien zur Globalisierung, Manutius Verlag, Heidelberg, 2001, S, 161-180.

Kraus, Hans-Christof, „Das Geheime Deutschland: Zur Geschichte und Bedeutung einer Idee", Historische Zeitschrift, Band 291, Oldenbourg , 2010, S. 385-417.

Kroll, Frank-Lothar, „Die kupierte Alternative, Konservatismus in Deutschland nach 1945" in: Die kupierte Alternative, Konservatismus in Deutschland nach 1945, Frank-Lothar Kroll (Hrsg), Duncker \& Humblot, Berlin, 2005, S. 3-24.

Laak, Dirk, Van, "From the Conservative Revolution to Technocratic Conservatism" in: German Ideologies since 1945, Jan-Werner Muller (ed.), Palgrave Macmillan, London, pp. 147-160.

Lewandowsky, Marcel, Alternative für Deutschland (AfD), a New Actor in the German Party System, Friedrich-Ebert-Stiftung, Berlin, 2014.

Lisson, Frank, Die Verachtung des Eigenen, Über den kulturellen Selbsthaß in Europa, Antaios Verlag, Schnellroda, 2019.

Mohler, Armin, Tendenzwende für Fortgeschrittene, Criticon Verlag, München, 1978.

Mohler, Armin, Von rechts gesehen, Seewald Verlag, Stuttgart, 1974.

Mohler, Armin, Was die Deutsche fürchten, Seewald Verlag, StuttgartDegerloch, 1965.

Muller, Jerry Z, „German Neo-Conservatism, ca. 1968-1985: Hermann Lübbe and Others" in: German Ideologies since 1945, Jan-Werner Muller (ed.), Palgrave Macmillan, London, pp. 161-184. 
Novak, Arndt, Schick, Jonas, „Deutschland von reschts“, Freilich, No. 2, 2019, S. 22-35.

O'Sullivan, Noël, „The New Right: The Quest for a Civil Philosophy in Europe and America" in: Roger Eatwell, Noël O'Sullivan (ed.) The Nature of the Right: American and European Political Thought Since 1789, Printer Publishers, London, 1989, pp. 167-191.

„Programm für Deutschland“, Das Grundsatzprogramm der Alternative für Deutschland, Berlin, 2016.

Ritter, Gerhard, Carl Groedeler und die deutsche Widerstandsbewegnung, Deutsche Verlags-Anstalt, Stuttgart, 1956.

Schelsky, Helmut, Systemüberwindung, Demokratisierung, und Gewaltteilung. Grundsatzkonflikte der Bundesrepublik, C. H. Beck, München, 1974.

Schildt, Axel, "Anpassung und Lernprozesse. Wideraufstieg und Erneuerung des deutschen Konservatismus nach 1945“, in: Michael Großhei, Hans Jörg Hennecke (Hrsg.), Staat und Ordnung im konservativen Denken, Nomos Verlag, Baden-Baden, 2013, S. 189-209.

Schoeps, Hans Joachim, Die Ehre Preussens, Friedrich Vorwerk, Stuttgart, 1951.

Schrenck-Notzing, Caspar, von, Charakterwäsche. Die Re-education der Deutschen und ihre bleibenden Auswirkungen, Ares Verlag, Graz, 2015.

Schrenck-Notzing, Caspar, von, Konservative Publizistik. Texte aus den Jahren 1961 bis 2008, Föderstiftung konservative Bildung und Forschung, Berlin, 2011.

Schwilk, Heimo, Schacht, Ulrich, (Hrsg.), Die selbstbewusste Nation: "Anschwellender Bocksgesang" und weitere Beiträge zu einer deutschen Debatte, Ullstein, Berlin, 1994.

Scruton, Roger, How to be a Conservative, Bloomsbury, London, 2014.

Sven-Uwe Schmitz, Konservativismus, VS Verlag für Sozialwissenschaften, Wiesbaden, 2009.

Verfassungsschutzbericht 2018, Bundesministerium des Innern, für Bau und Heimat, Berlin, 2019.

Weißmann, Karlheinz, Armin Mohler. Eine politische Biographie, Antaios Verlag, Schnellroda, 2011.

Weißmann, Karlheinz, Das konservative Minimum, Antaios Verlag, Schnellroda, 2009. 
Weißmann, Karlheinz, Kurze Geschichte der konservativen Intiligenz nach 1945, Institut für Staatspolitik, Schnellroda, 2011.

Winckler, Stefan, „,Konservative Intelligenz in vereinigten Deutschland“ in: Die kupierte Alternative, Konservatismus in Deutschland nach 1945, FrankLothar Kroll (Hrsg), Duncker \& Humblot, Berlin, 2005. S. 323-347.

Zitelmann Rainer, „,Die totalitäre Seite der Moderne“, in: Michael Prinz und Rainer Zitelmann (Hrsg.), Nationalsozialismus und Modernisierung, Wissenschaftliche Buchgesellschaft, Darmstadt, 1991, S. 1-20.

Zitelmann, Rainer, „Position und Begriff - Über eine neue demokratische Rechte" in: Heimo Schwilk, Ulrich Schacht (Hrsg.), Die selbstbewusste Nation: "Anschwellender Bocksgesang" und weitere Beiträge zu einer deutschen Debatte, Ullstein, Berlin, 1994, S. 163-181.

Zitelmann, Rainer, Weissmann, Kralheinz, Grossheim, Michael, (Hrsg.), Westbindung. Chancen und Risiken für Deutschland, Propyläen, Frankfurt am Main, Berlin, 1993.

Živanov, Sava, „Doprinos 7. Kongresa KI određenju socijalne prirode fašizma" u: Fašizam i neofašizam, Fakultet političkih nauka i Centar društvenih djelatnosti SSOH, Zagreb, 1976, str. 288-297.

\section{Izvori sa interneta}

Adam, Konrad, „Muttis Ödnis“, Junge Freiheit, 31. 8. 2012, http:/ /www.jfarchiv.de/archiv12/201236083151.htm 25/4/2020.

Henkel, Hans-Olaf „,Der deutsche Migrations-Skandal“ in: Cicero, https:// www.cicero.de/wirtschaft/der-deutsche-migrations-skandal/38250 20/4/2020.

"Hitler im Parlament", Frankfurter Allgemeine Zeitung, https:/ / www.faz. net/aktuell/politik/bundestagswahl/internationale-reaktionen-aufdie-bundestagswahl-15216062.html?printPagedArticle=true\#page Index_8 31/5/2020.

Jongen, Marc „Das Märchen vom Gespenst der AfD“, Cicero, 22. 1. 2014. http:/ / cicero.de/berliner-republik/afd-ein-manifest-fuer-einealternative-fuer-europa/56894 25/4/2020.

Lucke, Bernd, „Euro-Retter auf der falschen Spur", Frankfurter Allgemeine Zeitung, 11. 6. 2011. http://www.faz.net/aktuell/wirtschaft/eurokrise/ 
wirtschaftsordnung-euro-retter-auf-der-falschen-spur-1494362-p5.html 25/4/2020.

Sotscheck, Ralf, „Nicht naiv Testballons jagen“, taz, https:// taz.de/DebatteMit-Rechten-reden/!5555657/ 31/5/2020.

\section{Dušan DOSTANIĆ}

\section{THE RIGHT AS A SCARECROW: THE CASE OF THE ALTERNATIVE FOR GERMANY}

Abstract: During the last few years, there has been a lot of talk about the rise of the Right, which was commonly perceived as a potential threat or a security challenge. In this paper, the author questions the plausibility of this widespread assertion. Since every European country can be seen as a separate case, the author is dealing only with the situation in the Federal Republic of Germany. Germany is important because of its particular historical experience with rightwing totalitarianism. Also, for a very long time, Germany was the only major European country without a right-wing party in parliament. The paper is divided into four parts. In the first part, the author is dealing with the history of German Right after the Second World War because the alleged rise of the Right can be viewed only from a historical perspective. In the second part, we consider the Alternative for Germany (AfD) as the most important German right-wing party, and in the third part, we are talking about the Right outside of the AfD. The fourth part is dedicated to the issue of international cooperation of right-wing parties.

Keywords: right-wing, conservatism, the FR Germany, the Alternative for Germany, security. 